Article

\title{
An impact analysis concerning the effect of scandals on sustainable consumer purchase
}

\author{
Simona Vasilache ${ }^{*}{ }^{*}$ Cynthia Incze ${ }^{2}$ and Cristina Veith ${ }^{3}$ \\ 123 Bucharest University of Economic Studies, Romania; simona.vasilache@gmail.com (S.V.); \\ incze_cynthia@yahoo.com (C.I.); christineveith@yahoo.de (C.V.) \\ * Correspondence: simona.vasilache@gmail.com
}

\begin{abstract}
The idea of the current research started from noticing a major gap in the customer behavior literature - researchers have scarcely analyzed the impact of scandals on the customer purchase decision in the case of celebrity endorsement. Using a quantitative approach based on questionnaires, 101 people were asked about their opinions, the goals being to find out if people are influenced by the celebrity scandals, if people tend to have different reactions in terms of consumer purchase decision when it comes to various different negative actions carried on by the endorsers - will a murder upset the customers more than an infidelity scandal? - and if there are any differences in treating Romanian and foreign celebrities once they would enter into such a scandal.

The results of the survey suggest that Romanians don't really care about the scandals of the endorsers when being in front of the shelf. No matter the felony or the bad things done by the endorser, the local customers will continue to buy the products they used to buy, the occurrence of scandals having relatively no impact over their actions. Furthermore, no significant differences in attitude could be observed between brands endorsed by foreign celebrities and brands endorsed by local ones, when such star would enter into trouble.
\end{abstract}

\section{Introduction}

In the today's world, the ways in which brands and consumers are interacting had changed dramatically. On all layers, the communication tactics had suffered transformations, the industry today being totally unrecognizable compared with the one several decades ago.

According to Christa Carone (2021) chief marketing officer at Xerox, the consumer is bombarded each day with more than 3000 messages, out of which an average person is able to remember only four. Clutter had obviously become a great issue, being more and more difficult for a brand to send one of those 4 messages that the client may remember. Analyzing the typology of the successful messages, we can observe that they use similar strategies, the persuasion, the creativity and the entertainment being use intensively.

The usage of appeals - humor, music, recognition, fear, sex, subliminal messages - was found to be another way in which advertisers could break the clutter and increase the consumer's motivation to process the communicated message and, as a result of that, to interact with a brand at a later stage. Among this appeals, the celebrity endorsement has a very distinctive role, the advertising agencies investing immense amount of money in stars that look to be "marketable", a trend that appear to be on an increasing slope every year.

Celebrity endorsement, as a way to advertise and attract customers, is not at all a new approach, being something as old as the advertising itself. The institution of "royal warrants of appointment", in which companies supplying goods or services to the Royal Families around the world were allowed to advertise this fact has already reached several hundreds of years of history, being actually one of the first forms of celebrity endorsement. Obviously, times have changed and alongside with them, the communication habits and the 
technology used to support communication - the modern celebrity endorsement, the way we know it today, appeared somewhere in the dawns of the XX century and developed exponentially ever since in parallel with the development of the media channels.

In a world more and more globalized and connected to information channels, the global brand endorsers - usually stars from various activities, extremely well known all over the world - emerged to be a logical step in the development of the advertising strategies. Celebrity endorsement is not, however, a panacea for breaking the clutter and comprises many weak points: the celebrities may endorse too many products in the same time and may not appear trustworthy, little match between the endorser and the product may occur or - one of the worst cases - the celebrity may get into trouble, damaging its brand equity and, alongside with it the brand equity of the product endorsed.

This final point is actually extremely interesting and little analysis was carried on in the literature, in order to find out if there is actually a link between the scandals associated with the brand endorsers and the consumers' intention of purchasing that endorsed product.

Recognizing this gap (literature had focus almost completely on highlighting the positive aspects of celebrity endorsing), this paper will try to come with an answer to this aspect, following a quantitative research based on the answers of 101 Romanian young people. The increase focus over scandals - so negative events in the lives of the endorsers - was not a random one: negative events regarding stars are getting much more media coverage than positive ones, are impacting more the customers and are often easier to remember by them, thus making the research significantly easier.

\section{Research objectives}

Our study is intended to provide an answer to the following research objectives:

a) The first objective is to find out if there is there a link between the occurrence of scandals in the lives of the celebrities and the customers buying intentions. In other words, are customers reluctant to purchase a product recommended by a celebrity that just entered into some sort of trouble? This is actually the main research question, representing in the same time an aspect that seemed to be treated with less attention by the literature so far.

b) Check if people are having different reactions in terms of consumer purchasing decision when it comes to different negative actions of the celebrities. In other words, the research will try to find out if a regular customer is having the same reaction towards the endorsed brand no matter the scandal in which the celebrity has fallen, or on the contrary, there are some actions that customers are willing to forget and some which are capable to disturb them more. If Lionel Messi will cheat his wife or will kill her with gunshots, will it be the same thing for the brand image of Nike?

c) Finally, the third research objective of this paper is to observe if Romanian youngsters - the target group of this study - are treating Romanian celebrities and foreign ones in the same ways once the scandal is occurring in terms of buying decisions. In other words, the conclusions discovered for the first two objectives was analyzed, in order to check if they are applicable in the same ways both for an international celebrity and a local one. In order to achieve this goal, specific case studies surrounding scandals in which local and international celebrities were involved was delivered to the respondents, who was asked to express their feelings and opinions regarding them.

\section{Literature review}




\subsection{Advantages and disadvantages associated with advertising}

Advertising is not a panacea - it will not boost sales of a faulty product and it will not transform a terrible product into a fabulous one. Business people must always understand the fact that advertising should remain a complementary activity, one that has a role only in raising awareness and determining customers' purchase. No matter how effective advertising may be, it must be supported by a clear quality offer of the product and service - a dissatisfied customer is likely to avoid a second purchase, despite being reached by advertising and retaining its message.

Cravens and Piercy (2013, p. 351), referring to the advantages of using advertising to communicate with buyers, are remembering the "low cost per exposure, the variety of media, the control of exposure, the consistent message content and the opportunity for creative message designs". The same authors are observing a vital aspect regarding advertising' benefits: the fact that the appeal and message can be easily adjusted nowadays, according with the communication objective settled- this is such a critical point today, when appeals (including celebrity endorsement) are used more and more by communication departments in order to attract the consumer's attention and to make him remember the corporate message.

Barringer and Ireland (2010, p. 391), on the other hand, are referring to advertising's great power of building brand and product awareness and of allowing people to associate with the product and service advertised. Their direction is also confirmed by Belch \& Belch $(2012$, p. 19) who believes that advertising will remain a critical part of the integrated marketing communication (IMC) in the future, due to the fact that it is "the most cost effective way to reach large numbers of consumers" and "a valuable tool for building company or brand equity and a powerful way to provide consumers with information, as well as influence their perceptions".

While the benefits of the advertising seem very obvious, there are always some drawbacks when discussing about this activity. Some of those disadvantages have already been widely discussed in the doctrine, whereas others are that observable that they don't even need to be demonstrated or discussed. We are bombarded with thousands of messages every single day and it is more and more difficult to remember them or to make the distinction between them - this lead to an unusual situation in which advertising became much more intrusive, following us in our private lives (mobile phones ads, internet cookies, toilet ads) and exciting all our senses.

After analyzing the benefits of advertising, Barringer and Ireland (2010, p. 391) had also tried to systematize the red flags of it: the low credibility, the often very difficult task of targeting correctly the ad ("a high percentage of the people who will see the ad will not be interested"), the relative costliness compared to other forms of promotion and as discussed before, the perception that advertising is intrusive.

One of the most important problems in connection with advertising usage, also spotted by the two authors, is he so called message clutter - perfectly described by Christa Carone's words in the beginning of this paper. When the consumer is able to remember only 4 of the 3000 messages sent to him daily, it is clear that advertisers have a major problem and that some solutions, other than the conventional ones, have to be found.

\subsection{The clutter - and how to overpass it}

Shimp (2010) refers to clutter as to "a state or condition of confusion or disorderliness", a situation provoked by a large volume of advertising messages that a regular consumer is obliged to face every day, coming from a plethora of transmitters from various markets and caused by the huge degree of competition that these transmitters are facing.

The situation was also observed by Belch and Belch (2012) who, after regarding clutter as "the amount of advertising in a medium", discovered that one of the most important problems in advertising nowadays is being effective in catching consumers' attention. The two authors understood that "the large number of ads we are bombarded everyday makes it difficult to break through the clutter" (p. 179) and argued that it is more and more necessary to think outside the box in order to avoid this problem. It is actually a conclusion reached 
also by Chandon, Maazoul and Khalbous (2013), who studied extensively the effects of clutter on a big sample of students.

The problem of the clutter had already received wide spaces in the advertising literature. Brown and Rothschild (1993), Hammer, Riebe and Kennedy (2009) and more recently, Jeong, Kim and Zhao (2011) have analyzed the impact of clutter in television and not only, concluding that it is "a factor that reduces advertising effectiveness by causing avoidance behaviors and memory inference".

There were scholars who tried actually to analyze, understand and describe the dimensions of the clutter. Ha and McCann, in a study of 2008, observed that this element has three "physical dimensions" - the quantitative one (meaning the total number of ads), the competitive one ("the degree of exclusivity from like brands in the category") and the intrusiveness ("the degree of facilitated forced exposure such as pre-roll advertising"). Obviously, when discussing about negative impacts of clutter in advertising - and especially correlating this problem with the necessity of using celebrity endorsement - it is obvious that it is the quantitative dimension that we are more interested in.

Nelson-Field, Riebe and Sharp (2013) are observing that normally, there is a relationship between the price of advertising and clutter. Clutter can be reduced, if advertising costs are getting bigger and fewer companies would afford to advertise, the opposite is also valid: "doubling clutter potentially halves the price of advertising space".

But are there any ways to overpass the clutter in a world more and more focused on consumption and on stimulating customers to buy things? The answer is obviously yes and some hints have already been given on this aspect throughout the paper.

Clutter can be exceeded using several strategies: advertisers may use persuasion (practically to provide the audience enough motivation and opportunity to pay attention and finally to engage), creativity (it has the great advantage of differentiation - this solution would pull out the ad from the clutter and hopefully will make it easier to remember by the consumer, due to its impact) and the meaningful messages (that are having an emotional impact over the target - usually it's about entertainment) are all excellent ways to reach this objective and have been used with lots of success in the past.

There are practically unlimited ways of obtaining emotions from the consumers with ads, this being actually one of the goals of each advertiser. When it comes to breaking the message clutter, fewer things are working better than the usage of appeals. Belch and Belch (2012) are analyzing extensively the idea of appeals as ways to break the clutter. Several examples of appeals can be given, such as to better understand what an appeal is and how it functions: recognition, belonging, scarcity, music, subliminal messages, sex appeals, guilt, fear, humor, logic, status and ... celebrity endorsement. Inserted into ads, these elements have significantly bigger chances to be noticed and to make the message easier to remember.

Speaking about appeals, Voss (2009) experienced the effect of humor in advertising, focusing on humor with negative consequences. Indeed, the author discovered that consumers tend to remember these kinds of ads, proving the efficiency of the method. Similarly, Blackford et. al. (2011) analyzed the impact of humor and violence, whereas, Charry and Demoulin (2012) researched intensively the efficiency of threat appeals over the children. All those researchers understood that indeed, getting after the emotions of the public has a positive effect, the advertising message being significantly easier to spot and retain.

Clearly, the key idea behind any insertion of appeals in ads is creativity. There are lots of authors who already tackled the idea of creativity and discovered that indeed, it is an element that often creates a difference.

Kirby (2013), after giving several examples of high-creativity campaigns - campaigns which managed to stand out of crowd - concludes that "as long as companies are selling, consumers will need persuading and the creativity of advertising will never cease". Reinartz and Saffert (2013) tried to create an in-depth analysis of the creativity in advertising, finding that "an euro invested in a highly creative ad campaign had nearly double the sales impact of an euro spent on a noncreative campaign" and that "the conservative approaches adopted in many product categories are leaving money on the table."

From the multitude of appeals used by advertisers, this study is focusing on the celebrity endorsement. Much more than a simple trend, the usage of celebrities in order to promote product or services started to become something quite regular - Solomon (2009) discovered that about $20 \%$ of the US ads are featuring celebrities, whereas Mukherjee (2009) is suspecting that in other countries, such as Japan, this percent is even higher. Similar numbers are incurring in the United Kingdom, where "on average, one in five UK advertisements features a celebrity" (Schimmelpfenning and Hollensen, 2013). 
Clearly, when faced to such impressive numbers, research must focus extensively on understanding and explaining the mechanisms that stand behind the usage of celebrity endorsement, its benefits and recommendations and, especially, the negative aspects associated with it.

\subsection{Celebrity endorsement}

The celebrity endorsement is not at all a new institution, being probably as old as the action of selling goods and services. People always aspired to live like the celebrities of their period, no matter the times, so it makes a lot of sense for a business to associate with a star. Even the idea of "royal warrants of appointment", so often used in the second half of the second millennium is at its base a form of celebrity endorsement, since the merchants were taking great pride of providing goods and services to the royal families and were advertising this aspect.

Obviously, the cinema's rise had the effect of increasing significantly the fame of the actors and real celebrities started to emerge, alongside with the modern celebrity endorsement. The activity received another boost after 1930, when the commercial radio started to take off and even more after 1950, together with the television programs (McDonough, 1995).

McCracken (1989, p. 310) was among the first who actually tried to define the idea of celebrity endorsement. For him, a celebrity endorser was "an individual who enjoys public recognition and who uses this recognition on behalf of a consumer good by appearing with it in an advertisement". More recently, Carrillat, D'Astous and Lazure (2013) defined the celebrity endorsement as a marketing-communication strategy that brands commonly use and which implies and association between the endorsers (as spokespeople) and the brand.

Perhaps Mukherjee (2009) had come with the most comprehensive definition of the terms - for him, the endorsement was a channel of brand communication in which a celebrity acts as the brand's spokesperson and certifies the brand's claim and position by extending his/her personality, popularity, stature in the society or expertise in the field to the brand.

The idea of celebrity endorsement, being impossible to explain in any other way than in conjunction with the celebrities gives birth to another question: what is a celebrity?

It is a question that interested the scholars from a very long time, especially in connection with the advertising activity, and research into this matter have been carried on very early - just two decades after the television emergence, Friedman and Friedman (1979) were explaining the term "celebrity" as "an individual who is known to the public (actor, sports figure, entertainer, etc.) for his or her achievements in areas other than that of the product class endorsed". The two authors were explaining that the celebrities enjoyed a lot of public recognition from people, having a great awareness and being extremely attractive.

\subsection{Benefits of celebrity endorsing}

Brands are taking advantage of celebrity endorsing for a long time now and doctrine had had more than enough time to analyze the benefits associated with such moves.

Mukherjee (2009) refers to the so called 4-q's: quick saliency, quick connect, quick shorthand for brand values and quick means of brand differentiation. Explained, these 4Qs are referring to the following things: a) the saliency means that due to the star, the advertisement is easily observable b) the connection refers to the fact that due to the image of the starts, the ads are capable of creating an easier connection with the target c) the quick shorthand means that if the endorser is selected correctly, the star will transfer the message very easy and quickly and d) the quick means of brand differentiation is actually meaning that, if in a certain domain, there is no brand using celebrity endorsement, the one that makes a first move in that direction will differentiate very strong and will gain a clear advantage.

Erdogan (1999) had also tried to sum up the benefits of the celebrity endorsement, finding five main pillars; the increased attention, the image polishing, the brand introduction, the brand repositioning and the underpinning of global campaigns. In the same piece of research, Erdogan is pointing out the hazards associated with each benefit and potential workarounds such as to avoid their effects. 
At their own, Belch and Belch (2012) believe that companies are spending immense budgets on celebrity endorsements because they believe that "celebrities have stopping power (...) they draw attention to advertising messages in a very cluttered media environment" and because they "think a popular celebrity will favorably influence consumers' feelings, attitudes and purchase behavior". Not least, the two authors also believe that the tactic has also a significant role when it comes to "enhancing the target audience's perceptions of the product in terms of image and/or performance", that being the case, for instance, of an advertisement where Cristiano Ronaldo recommends Herbalife products, products that theoretically should enhance the sportive capacities of the buyers.

A number of other authors analyzed the phenomenon from other perspectives: Misra and Beatty (1990) referred to the ease of remembering the advertising messages, Silvera and Austad (2004) to better results when it comes to brand evaluations, Erdogan and Baker (1999) to enhancing attention from the consumer. A number of authors (Mathur, Mathur and Rangan, 1998; Agrawal and Kamakura, 1995) also referred to the positive financial results encountered by the companies using celebrity endorsement in comparison with those who don't, seen from the bonds and shares evaluation perspective. Indeed, in a world sensitive to every cough when it comes to financial markets and securities or equity's quotations, hiring a celebrity to promote your product can have a lot of effects on the stocks market: the companies prices will almost always go up, as the investors will gain confidence in the organization. Also, in some cases the shares of the competitors will also suffer depreciations, as a consequence of the demand for shares going up in the company using endorsements. Doctrine had also analyzed - although in a clearly smaller degree than the benefits - the potential problems associated with using celebrities to promote various products or services of a company.

Belch and Belch (2012), understanding that celebrity endorsing is a tactic that cannot be skipped in the today's advertising, had however identified several red flags that marketers should take care of when using such approach. The four authors had identified five main points of concern: the overshadowing of the product, the overexposure, the target audiences' receptivity, the matching between the celebrity and the endorsed product and the individual risk associated with the endorser selected.

When it comes to overshadowing the product, the two authors are referring to the situations in which, after a celebrity endorsement, the product gets little benefit from it due to the fact that the celebrity did more to sell $\mathrm{him} / \mathrm{her}$ than the endorsed brand. This has often little to do with the will of the star, actually, the endorser may really wish things to go in the right direction, but due to great brand awareness of the celebrity, customer focus may fall on them instead of falling on what they recommend.

The problem of overshadowing was also recognized in the literature by other authors. Erdogan (1999) and before him Rossiter and Percy (1987) discussed about this issue, observing that often, the consumers focus their attention on the celebrity and fail to notice the brand which is promoted. It is an unfortunate situation which actually means that the company had wasted its money completely, since little benefit is observable in terms of branding or selling the endorsed product.

The overexposure is one of the most frequent problems met in practice when dealing with celebrity endorsement. It is referring to those situations when a celebrity is used in too many advertisements and people start to lose confidence in that person. It is a problem that had been identified so correctly by Mowen and Brown (1981) who observed that customers are perfectly aware that celebrities are recommending products because of the fact that they are paid to do so. On this climate of doubt and disbelief, a celebrity that is endorsing too many things at the same time may look even more avid for money and the customers' skepticism may actually go even higher than normal. Belch and Belch (2012, p. 187) are giving the example of Cher, but even today we can notice a lot of advertisements with football stars Lionel Messi or Cristiano Ronaldo, promoting all sorts of products and services and there are so little chances that the two superstars are actually using any of them.

Other authors have related to the issue of overexposure, too. Erdogan (1999) is speaking about the "greed and the subsequent overexposure" of the stars and Mowen and Brown concluded that when a celebrity associate its image with multiple brands, the effect of the association is fading for each of the endorsed products and the consumers are getting confused.

The target audience receptivity is actually a less-studied theme. It is referring to those situations when either the industry or the brand's image is not recommending the usage of celebrity endorsements, or consumers are expert enough such as they will not be influenced by advertisements. An example would be Dove soaps, a brand which by tradition, is not hiring celebrities for their advertisements, but regular people. The logic behind 
this move is the fact that Dove itself is presented as a product for the average consumer and not for the celebrities. On the other hand, there may be fields when celebrities endorsing is really not useful - for instance, the tools industry. Stanley Tools is one of the biggest tool makers of the world, its target market being workers and builders around the world - these guys know their job, know what tools are good and not, and any advertisement - even one with a superstar - will probably fail to convince suddenly the customers on buying Stanley.

The question of the matching between the celebrity and the endorsed product is a quite sensitive issue. In order for the advertisement to be solid and to fulfill its goals of convincing people to buy (in other words, to influence customer behavior), the endorser must have certain attributes that make him suitable for such a task. An ad in which Celine Dion is recommending Goodyear tires will surely encounter very small success. The question between the endorser-product match-up will actually be developed further, when analyzing the socalled TEARS model.

Finally, the most important problem to be analyzed by a company management before deciding upon an endorser is the risk that the celebrity is presenting, when it comes to negative events that would affect the endorsed brand's equity and image. Nike cut the support for Lance Armstrong's foundation Livestrong after the athlete admitted that he had used performance-enhancing drugs in order to obtain his victories in the Tour of France, observing that the association with the cyclist started to have a negative impact over the company's image (Macur, 2013). Previously, the company had cut down the sponsorships towards Lance Armstrong himself, the company's board stating clearly that cheating and illegal performance enhancing drugs usage are against all Nike's values (Belson \& Pilon, 2012).

It is clear that a celebrity's behavior is implying a risk for the company whose products or services this celebrity is endorsing (Till and Shimp, 1998) and for this exact reason, attention must be given when an endorser is selected. There are celebrities which by default are "trouble", a company signing with them expecting in any minute something wrong to happen: Mike Tyson is a classic example, but even more recently, stars like Charlie Sheen, Lindsay Lohan or AC Milan's top star Mario Balotelli are entering so often in trouble, that a company signing with them an endorsement is impossible not to expect a false step from their part at some point.

The recent history proves a wide range of scandals that may arise in the lives of celebrities, scandals which brought alongside with them endorsement contracts' termination or fines (Goldman and Bennett, 2011): infidelity (Tiger Woods cheating scandal made Tag Heuer's bosses end the agreement), doping (famous runner Ben Johnson lost his Diadora contract after failing a steroid test), drugs (Michael Phelps was found to smoke marijuana and Kellogg's left the table), murder (O.J. Simpson case and Hertz, the car renting company), rape (Lakers' star Kobe Bryant and McDonalds), domestic violence (Mike Tyson had repeatedly beat his wife, thing which made Pepsi's officials terminate his contract) or any other thing which may irritate public opinion - celebrities are quite capable of entering into trouble so the imagination is the limit.

Till and Shimp (1998) developed more on the idea of negative celebrity information. The two authors also stated that widely publicized incidents may, at some point become a liability for the brands endorsed.

Belch and Belch (2012) admit that "the usage of celebrity endorsers can be a very expensive and high-risk strategy", recommending shareholders to look carefully into the past of the celebrity (personally and professionally) such as to be as little as possible taken by surprise. Also, the same authors are recommending the legal departments of the companies to enclose clear contract, with obligations and penalties for the celebrity, such as to be able to end quickly a contract and eventually, recover some money if the image prejudice is taking place.

Carrillat, d'Astous and Lazure (2013) also remind about the negative effects that a celebrity entering into a scandal may bring to the stock value of the company owning the brand endorsed. However, the three scholars are making a clear distinction between intentional and non-intentional acts, observing that sometimes, when celebrities are encountering a negative happening without their will, people tend to empathize with them. It is actually a conclusion reached also by Louie, Kulik and Jacobson (2011), who analyzed the case of Nancy Kerrigan, a well-known ice-skater and a prominent figure of the Olympic Games. The three authors discovered that after the athlete was attacked - so some negative information - the stock market value of the company she was endorsing actually increased. Money, Shimp and Sakano (2006) were another group of researchers who independently tried to check the effects of negative information compared to positive one in the life of the endorser. The three researchers concluded that the celebrities "behaviors who are perceived as beyond their control" may actually "generate sympathetic emotions among celebrity worshipers rather than 
contempt". Also, in such a case, the three scholars are suggesting that the agreement with the celebrity has to be preserved, since no case of "hot-potato" will take place and no negative impact over the company was recorded.

\subsection{Picking the correct endorser - models of influence}

Obviously, the advertising literature had also covered the topic of picking the correct endorser for a brand, numerous models and recommendations being developed by the scholars. The most frequent, the doctrine is speaking about four models to be used: the source credibility model, the source attractiveness model, the product match-up hypothesis and the meaning transfer model.

Initially mentioned by Hovland and Weiss (1951), the source credibility model was latterly discussed again in other papers by other authors: Hovland, Janis and Kelley (1953), Ohanian (1990) and Erdogan (1999). Basically, the way the model was developed initially, it is focusing on two main dimensions: the expertise and the trustworthiness.

Obviously, the trustworthiness of the celebrity will come from its way of being and integrity and should be clearly perceived by the target audience (a target audience which feels that it is lied makes the endorsement totally useless). The endorser must not - at any point - be suspected to gain something from the endorsement, especially because, as Smith (1973) observed, celebrities are by default regarded by the mass population as relatively fake when it comes to recommending a product.

The second element of the model is the expertise, defined by Erdogan (1999) as "the extent to which a communicator is perceived to be a source of valid assertions" and has to be seen also through the perspective of the trustworthiness. A celebrity expert in a field of activity has significantly bigger chances to be believed by the mass public in the event if he/she decides to endorse a product or a service somehow related to its regular activity: coming back to the example presented above, Celine Dion would clearly be a wrong choice when it comes to endorse Goodyear tires, but maybe she would really be suitable for some make-up or perfume brand, since she is perceived as an elegant person, careful with her image. Belch and Belch (2012) are actually giving a Celine Dion example as a "do not": in 2004, the Canadian superstar signed an celebrity endorsing contract with Chrysler, in what was soon to become one of the biggest advertising failures in the history of the American carmaker. Steinberg (2012) observed that while Chrysler did pay Celine Dion an amount between 10 and 14 million USD, the sales of the new models endorsed by the singer remained virtually unchanged.

The source attractiveness model was developed by McGuire in 1985, who regarded "attractiveness" as a cumulus of individual skills, personality, status lifestyle, talent, values and physical appeal. Starting from Cohen and Golden findings (1972) the model is functioning based a central process, called "identification", that is a situation in which the consumers are accepting the endorser's attitude behavior and preferences due to the fact that they identify with him/her. The advertisements are highly recommended to use attractive people (not only physical attraction, since the model is referring to much more than that), an attribute which according with previous research (Friedman, Termini and Washington, 1976) is actually able to generate much more intense shifts in the consumer purchase intentions compared to the situations when unattractive people are called in for appearing in the advertisements.

The match-up model, first brought in discussion by Forkan in 1980, is asking for a clear match-up between the product endorsed and the celebrity. Misra and Beatty (1990) discussed about this issue too, concluding that the match between the endorser and the brand endorsed depends greatly on public perception, in other words how "fit" is the celebrity image for the brand name and its characteristics. A clear example can come from Nissan's strategy when re-launching its super-sport car GT-R: the company hired as an endorser the Jamaican Olympic legend Usain Bolt, considered the fastest man alive and advertised the products under the slogan "What if the world's fastest man went even faster?". Clearly, between the GT-R's attributes and Bolt's image there is a strong similarity, both addressing to relatively young people, passionate about sports and performance and interested in nothing but the best.

The last model to be discussed is the one developed by McCracken (1989), the meaning transfer model. The way it was imagined, the model is implying three different stages: "the formation of celebrity image, the transfer of meaning from celebrity to product, and finally from product to consumers". According with the 
author, "the cultural meanings residing in a celebrity go beyond the person and are passed to the products", in a situation which practically means that the final goal of this model is to make the consumers feel that they are somehow similar with the celebrity in the event that they are using the good/service endorsed. At the end of the day, it is a question of "having a moment of stardom", in which the everyday people are allowed access to a little of the celebrity's lifestyle.

The reality is that we cannot speak of one single correct model of influence to be used. Instead, Shimp (2003) is proposing the TEARS model, a model which pretty much takes into consideration all the previous models expressed by the doctrine and combines them into a single set of requirements. Together with the NO TEARS approach for marketing managers, Shimp's observations seem to form the most comprehensive tools for selecting the right endorser, taking into consideration pretty much all the elements asked in order to convince the customers and reduce the risks associated with the celebrity.

The TEARS model, the way it was imagined, implies five main attributes, most of them being already discussed above, when analyzing others models of influence. the trustworthiness (T), the expertise (E), the physical attractiveness (A), the respect $(R)$ and the similarity (S). While the first three attributes are really straight-forward at this point, the other two may require some extra explanations. The $\mathrm{R}$ stands for respect, viewed by Shimp (2003, p. 298) as an element complementary to the A (physical attractiveness). While the attractiveness is seen as a form of the overall attractiveness of a celebrity, the R takes care of the inner side, being "a function" and a substantive element. At this point, respect is seen by van Nifterick (2009) as "the quality of being admired or even esteemed due to one's personal qualities and accomplishments", an element essential to any successful endorsement. Finally, the S, standing from Similarity is seen by Shimp (2003) as "the degree to which an endorser matches an audience in terms of characteristics pertinent to the endorsement relationship". It is quite clear that a celebrity matching the target audience was trusted more and the endorsement will have overall better results.

In his same book, Shimp had developed another model, the NO TEARS model, one designed for marketing and advertising practitioners, whose role is basically to assist them with a tool capable of making sure that "there was no tears" for the company, once the endorsement was signed (van Nifterick, 2009).

As mentioned before, the scholars had relatively avoided the topic of scandals and their effects when it comes to celebrity endorsing, preferring much more to write about the benefits and the mechanisms associated with closing such a deal with a star. Despite the relative lack of preoccupation towards this domain, there have been some authors who tried to determine if the assumption that the endorsed brand suffers a hit when the celebrated endorser gets into trouble is correct or not.

Thwaites et al (2012) suggest that in the cases when high match-ups exist between the celebrities and the brand endorsed, negative publicity around the star "is shown to have a significant impact on a celebrity's attractiveness and credibility". The two authors are strongly advising celebrities to understand that that "endorsing a brand does not stop after the ad has been shot", suggesting that a responsible attitude should be kept on all time. Carrillat, D'Astous and Lazure (2013) have a total opposite perspective: while agreeing that consumers are not passive listeners when it comes to "a negative event", the three authors are suggesting that companies should not break the contracts with the troubled celebrities in all cases: "a strong congruence between the two partners represents a situation where the brand would lose more by breaking off the endorsement deal than by maintaining it". On the other hand, when this congruence between the brand and the endorser is not really high, the authors suggest that the company is free to do whatever it wants, considering the other contractual elements (in other words, if they don't lose too much money by terminating the contract, they are free to proceed).

Till and Shimp (1998) note that the celebrity endorsement carries indeed a risk, since the advertiser has no control over the celebrity's future behavior and actions. Nevertheless, the two authors discovered that the risk of damaging the brand equity or of experiencing drops in sales is relatively low for the established brands when such a scandal is affecting their endorser - "the risk is potentially great for new or unfamiliar brands for which the association set is relatively scant and for which the celebrity is essentially the primary attribute on which consumers form evaluations of the brand".

Money, Shimp and Sakano (2006) have tried to give an answer to the question if negative information is really that harmful in celebrity endorsement. The three authors have carried on a comparative study in United States of America and Japan and discovered that in some cases, "celebrities' images may actually benefit, rather than 
suffer from some forms of negative press" and that very often, people are not disturbed by the troubles of the celebrities and consequently, their consumer purchase intention remains unchanged. The research suggest that, both in Japan and USA, the customers are relatively emphatic with the celebrities and tend to excuse their problems, especially when stars entered in trouble by mistake (actually, the study suggests that even Kate Moss snorting cocaine was seen by the consumers as an excusable thing and put on the behalf of the difficult life of a world top model - consequently neither her popularity or the purchase intention for the products endorsed by her were really affected).

Bailey (2007) was another author who tried to see if young consumers' purchase intentions are suffering any modifications when it comes to negative information regarding the celebrities. His findings are quite interesting, since according with him, "consumers generally might not be as turned off from a brand if a celebrity involved in a controversy is not strongly associated with the brand". As a solution for this problem, the author is recommending the usage of multiple endorsers (a strategy that Nike for instance is constantly using), in order to reduce the exposure (and the inevitably associations) on only one person. It was also Bailey (2007) who discovered that people have different reactions and experience different degrees of attitude changing, in accordance with the nature of the scandal in which the celebrity is in - some sex photos will clearly not have the same impact over consumers as a murder accusation. In all cases, Bailey suggest that there is indeed a liaison between the consumers perceptions and attitudes provoked by a scandal and their purchase intentions of the good endorsed by that celebrity. From this point of view, the author has an opinion closer to the ones expressed by Thwaites et al (2012).

\section{Methodology}

\subsection{Description and justification}

Starting from the theoretical concepts and from previous researches in advertising, this paper will determine the views of the Romanian people and should be able to come up with a clear picture regarding the ways in which our compatriots are influenced by endorsers. For this purpose, a survey was carried on. The choice of this methodology was not something randomly, a quantitative research being by far the most suitable way of tackling such a subject.

Just like numerous other authors, Creswell (2013) does not believe that there is a standard methodology for all research problems, one that can be applied in any circumstance. Quite the opposite, the author believes that the choice between a quantitative, qualitative or mixed approach must be taken in accordance with the subject of the research. Relevant to the present study is the author's idea that when "the problem is identifying factors that influence an outcome, the utility intervention, or understanding the best predictors of outcomes" a quantitative approach may be recommended. It is the exact situation of this study, which tries to determine, based on some factors whether Romanian people may be influenced in some ways by scandals when deciding upon buying a certain product.

Additionally, there are other reasons that stand behind the decision of selecting a quantitative research methodology: some of them are highlighted by D'Onofrio (1999) who considers that a quantitative research is cheap and - when carried online - comes with the extra-benefit of saving paperwork. Also, the fact that there are some previous works in the same field (Money et al., 2006; Bailey, 2007) which used this method was another extra-reason for choosing a quantitative research.

\subsection{Target group}

The target group was inspired by the research made by Money et al (2006), for celebrity endorsement and negative information, although that piece of work was referring to a cross cultural comparison between USA 
and Japan. Due to the financial and geographical limitations of the research, the target group was made of Romanian people, located in the capital city of the country, Bucharest.

Regarding their age, the research will focus on young people, just like Money et al.'s study (2006). Since there is not a clear definition in the literature for the term "young", a specific age group had to be determined. It is reasonable to assume that a relevant age group for the research was made of people having up to 35 years old. No special requirements was made for the respondents' genre or education, the greater the variety, the better the results, from a statistical point of view.

\subsection{Sampling}

The survey was carried on a number of 100 young people, between 15 and 35 years old, living in Bucharest. These people were contacted directly, on the streets of Bucharest and were asked to complete a 2-minutes bilingual electronically survey available on a tablet. The preference for such a method was not a random one - since people are busy and generally unwilling to stop and complete questionnaires, such a method may ease things and increase the responsiveness rate.

The survey was previously designed using one of the numerous web-based survey solutions (Google Docs). Since the respondents answered also online, an electronically database with answers was created automatically, and the results were imported into SPSS.

\subsection{Statistical tools}

The SPSS Statistics 22 was used, such as to be able to come up quickly and efficiently with the results needed for the study. The preference for SPSS was not randomly, the software having a specialized interface that accepts and converts automatically the results from the Google Databases (remember that the survey was collected electronically in Google Docs) into SPSS-format databases. On the default setting, when exported from Google, the set of information obtained from the questionnaire cannot be opened directly with Statistical software, so, such a conversion of information is essential in order to analyze everything statistically.

\subsection{The survey}

The survey was developed taken into account the three objectives of the research, containing questions that a) assess the degree in which the Romanians are changing their purchasing intentions after the occurrence of a scandal in the life of the product' endorser b) assess the differences in treating the local and foreign celebrities once a scandal is occurring and c) check if some kind of negative evens are having a bigger influential power than others (in other ways to see if there is a difference between a minor scandal and a really big one in terms of the ways in which customers relate to the brands endorsed).

The survey, the way it was designed, is composed of sixteen questions and it was inspired from the previous research carried on by McGuire (1985), Money et al. (2006), and Bailey (2007). Some of its questions were also inspired from the research carried on by Skourti (2010) in Thessaloniki on quite a similar topic. Preference was given to closed questions, for the ease of analysis and also in order to make people' responsiveness rate bigger - from the perspective of the respondent, the questionnaire should therefore be easy to complete, less boring than others and quite clear.

In order to be able to analyze better the opinion of the respondents, five-points Likert Scales questions were used (actually ten of the 16 questions are having Likert-Scales based answers). This enables the researcher to observe much more detailed the people's feelings and increases the chances of obtaining valuable scientific results. 


\section{Results and discussions}

As mentioned before, a questionnaire (see Appendix 1) was developed, in order to check the views of the Bucharest inhabitants on the already mentioned subject of scandals in the lives of the celebrity endorsers. Several questions were asked, in order to reach the objectives of the research previously mentioned.

Table 2.1. The demographics of the participants

\begin{tabular}{|c|c|c|c|}
\hline Variable & Categories & Frequency & Percentage \\
\hline \multirow[t]{2}{*}{ Gender } & Male & 49 & $48,5 \%$ \\
\hline & Female & 52 & $51,5 \%$ \\
\hline \multirow[t]{5}{*}{ Age } & 0-15 (recoded 1) & 11 & $10,9 \%$ \\
\hline & 16-20 (recoded 2) & 13 & $12,9 \%$ \\
\hline & 21-25 (recoded 3) & 24 & $23,8 \%$ \\
\hline & 26-30 (recoded 4) & 30 & $29,7 \%$ \\
\hline & 31-35 (recoded 5) & 23 & $22,8 \%$ \\
\hline \multirow[t]{4}{*}{ Education } & Elementary School & $\beta$ & $3 \%$ \\
\hline & High School & 23 & $22,8 \%$ \\
\hline & Bachelor Degree & 41 & $40,6 \%$ \\
\hline & Postgraduate Studies & 34 & $33,7 \%$ \\
\hline
\end{tabular}

The respondents of the questionnaires were selected on the condition that they was maximum 35 years old. As observed, 101 people decided to help the research and provide an answer to the survey, their gender repartition being relatively equal. This will increase the value of the study, whose conclusions may apply to both genders, and not only to one of the two.

The variables of the age were recoded for statistical purposes. Calculating the percentages, we can affirm that the greatest majority of the respondents were people in their 20's (so between 21 and 30 years old), with a cumulative percent of $53,5 \%$, having a good level of education. $74,3 \%$ percent of the respondents have graduated a faculty, whereas 33,7 of them decided to continue their studies with post-graduate programs. These finding present a lot of relevance, for the purpose of the further analysis, being important to know exactly the typology of the respondents.

From the very question of the study, the answers are appearing quite unexpected. Asked if they buy product endorsed by celebrities, only $46,5 \%$ of them replied affirmatively, even if in the today's world, there is almost no chance of not buying - at least once - such a product when dealing with the weekly grocery shopping. The percentage of those who declared themselves unaware is striking, 39,6\% of the people asked ticking this option. The fact that people are not aware of the fact that they buy products endorsed by celebrities, correlated 
to the big percentage of those replying negatively to the question (almost $14 \%$ ) is a clear sign that - at least on Bucharest based-young people - the celebrity endorsement is not that effective as appeal.

Table 2.2. People influenced by celebrities

Do you buy products that are endorsed by celebrities?

\begin{tabular}{|l|l|l|l|l|}
\hline & & & & \\
& & & & \\
Frequency & Percent & Valid Percent & $\begin{array}{l}\text { Cumulative } \\
\text { Percent }\end{array}$ \\
\hline Valid 1,00 & 47 & 46,5 & 46,5 & 46,5 \\
3,00 & 14 & 13,9 & 13,9 & 60,4 \\
Total & 101 & 39,6 & 39,6 & 100,0 \\
\hline
\end{tabular}

The next 4 questions tried to assess the attitudes of the Romanian customer towards celebrities and the scandals they fall in. 34\% of the respondents declared themselves interested by the celebrities' personal lives, whereas some additional 9,9\% are "very interested". The respondents tend therefore to be curious about the daily existence of the stars, but when a scandal arises, their curiosity tend to be smaller: only a cumulated percent of $37,7 \%$ recognized that they want to be informed if a celebrity is involved in a scandal.

\section{Table 2.3. People's attitudes towards celebrities' personal lives}

Rate the following questions, 5 representing "strongly agree" and 1 "strongly disagree" / I follow the celebrity news because I care about their personal life

\begin{tabular}{|l|l|l|l|l|}
\hline & & & & \\
& & & & \\
Frequency & Percent & Valid Percent & $\begin{array}{l}\text { Cumulative } \\
\text { Percent }\end{array}$ \\
\hline Valid 1,00 & 9 & 8,9 & 8,9 & 8,9 \\
3,00 & 26 & 25,7 & 25,7 & 34,7 \\
4,00 & 34 & 21,8 & 21,8 & 56,4 \\
5,00 & 10 & 33,7 & 33,7 & 90,1 \\
& & 9,9 & 9,9 & 100,0 \\
Total & 101 & 100,0 & 100,0 & \\
\hline
\end{tabular}

Table 2.4. People's attitudes towards celebrities involved in scandals

Rate the following questions, 5 representing "strongly agree" and 1 "strongly disagree" / I want to know if a celebrity is involved in a scandal 


\begin{tabular}{|l|l|l|l|l|}
\hline & & & & \\
& & & & \\
Vrequency & Percent & Valid Percent & $\begin{array}{l}\text { Cumulative } \\
\text { Percent }\end{array}$ \\
\hline 2,00 & 20 & 12,9 & 12,9 & 12,9 \\
3,00 & 30 & 29,7 & 29,7 & 32,7 \\
4,00 & 23 & 22,8 & 22,8 & 62,4 \\
5,00 & 15 & 14,9 & 14,9 & 10,1 \\
Total & 101 & 100,0 & 100,0 & 100,0 \\
\hline
\end{tabular}

When it comes to the occurrence of scandals, the respondents seem to have a clear reaction towards the brand endorsed by the celebrity in trouble: they will continue to purchase. The result, as surprising as it may be, is strongly supported by statistical evidence: $60,4 \%$ of the people asked are strongly disagreeing or just disagreeing the affirmation that they will change their attitude towards the brands endorsed by a celebrity in trouble, whereas some additional $26,7 \%$ of them are still not decided. Only $12,9 \%$ of the respondents are actually saying that they are influenced by the endorsers' scandals when making the purchase intention.

\section{Table 2.5 Attitude changes when celebrities face a scandal}

Rate the following questions, 5 representing "strongly agree" and 1
"strongly disagree" / I change my attitude towards a brand if the celebrity
used is involved in a scandal
\begin{tabular}{|c|l|l|l|l|}
\hline & & & & \\
& & & \\
& Frequency & Percent & Valid Percent & $\begin{array}{l}\text { Cumulative } \\
\text { Percent }\end{array}$ \\
\hline Valid 1,00 & 30 & 29,7 & 29,7 & 29,7 \\
3,00 & 31 & 30,7 & 30,7 & 60,4 \\
4,00 & 9 & 26,7 & 26,7 & 87,1 \\
5,00 & 4 & 8,9 & 8,9 & 96,0 \\
Total & 101 & 4,0 & 4,0 & 100,0 \\
\hline
\end{tabular}

The percentages are actually even more surprising when it comes to those saying that they want the brand to stop using the celebrity that was involved in a scandal, a cumulated $64,4 \%$ of the respondents saying that they don't see such a move necessary. Such result may be seen and explained through the big number of people indifferent to the celebrities' scandals - apparently, for the Bucharest young consumer, the endorser and his/her foolish things are really not something influential in front of the shelf. 
Table 2.6. Attitude towards brands when celebrities face a scandal

Rate the following questions, 5 representing "strongly agree" and 1 "strongly disagree" / I want the brand to stop using the celebrity that was involved in a scandal

\begin{tabular}{|c|c|c|c|c|c|}
\hline & & Frequency & Percent & Valid Percent & $\begin{array}{l}\text { Cumulative } \\
\text { Percent }\end{array}$ \\
\hline \multirow[t]{6}{*}{ Valid } & 1,00 & 32 & 31,7 & 31,7 & 31,7 \\
\hline & 2,00 & 33 & 32,7 & 32,7 & 64,4 \\
\hline & 3,00 & 23 & 22,8 & 22,8 & 87,1 \\
\hline & 4,00 & 5 & 5,0 & 5,0 & 92,1 \\
\hline & 5,00 & 8 & 7,9 & 7,9 & 100,0 \\
\hline & Total & 101 & 100,0 & 100,0 & \\
\hline
\end{tabular}

The next set of three questions was regarded as highly important for the research, having the potential to come with an answer to the debate if people are treating Romanian and foreign celebrities the same when a scandal arises. Starting from the well-know real case of Tiger Woods, who had fallen into an world-scale infidelity scale while being under contract with Nike, the participants were asked about their intentions of buying Nike products in future. Similarly, in order to check the opinions towards the local stars, the participants asked to imagine the exact same situation, with Adrian Mutu, the footballer, being in Tiger Woods' shoes.

The results are the ones below:

Table 2.7. Example of Tiger Woods

Think of Tiger Woods, the famous golf player who was found to cheat his wife and provoked a great scandal. Considering the fact that he was promoting Nike at the moment of the incident, what was your reaction towards this brand?

\begin{tabular}{|l|l|l|l|l|}
\hline & & & & \\
& & & & \\
Frequency & Percent & Valid Percent & $\begin{array}{l}\text { Pumulative } \\
\text { Percent }\end{array}$ \\
\hline Valid 1,00 & 8 & 7,9 & 7,9 & 7,9 \\
3,00 & 26 & 25,7 & 25,7 & 33,7 \\
Total & 101 & 66,3 & 66,3 & 100,0 \\
\hline
\end{tabular}

Table 2.8. Example of Adrian Mutu

Now think of Adrian Mutu, the Romanian footballer and the star of Petrolul FC. Supossing that at the moment, he would be endorsing Nike 
shoes, what would be your attitude towards the brand if tomorrow you would hear that had cheated his wife?

\begin{tabular}{|c|c|c|c|c|c|}
\hline & & Frequency & Percent & Valid Percent & $\begin{array}{l}\text { Cumulative } \\
\text { Percent }\end{array}$ \\
\hline \multirow[t]{4}{*}{ Valid } & 1,00 & 9 & 8,9 & 8,9 & 8,9 \\
\hline & 2,00 & 29 & 28,7 & 28,7 & 37,6 \\
\hline & 3,00 & 63 & 62,4 & 62,4 & 100,0 \\
\hline & Total & 101 & 100,0 & 100,0 & \\
\hline
\end{tabular}

Clearly, it impossible to conclude that people are treating the local or the foreign stars preferentially. Put in the exact same situation (an infidelity scandal) the potential Nike buyers will purchase Nike in 66,3\% (in Tiger Woods' case) and 62,4\% (in Adrian Mutu's) of the cases. Moreover, only 25,7 and 28,7\% respectively of them declared that they "may not be interested in buying Nike, the percentages of those that would stop buying Nike having, in both cases, one-digit results. While it is indeed a difference between the numbers, the fact that it is so small is a clear indication that Bucharest inhabitants are really treating the celebrities the same when it comes to scandals, scandals which are generally unable to provoke shifts in the consumer purchase intentions of the respondents.

Although the two questions were designed only to test the differences between the attitudes towards local and international stars, its staggering results (referring to the great percentages of those saying that they would buy like nothing happened) are representing a clear indication that Bucharest people are really not influenced by celebrities when deciding what to buy, or better said, what not to buy.

In order to check the validity of the two questions concerning the attitude towards Adrian Mutu and Tiger Woods, a third question was also designed, asking directly the respondents to assess their attitude in the situation in which two celebrities - a local and a foreign one - endorsing products they normally buy, are entering into some disturbing scandals. Its results were somehow expected taking into account the answers from the previous two points: $72,3 \%$ of all respondents declared that they will treat the products endorsed by the two stars identically, either by keeping to purchase both of them, either by quitting the buying habitude for both.

Finally, the last five questions have to be analyzed together, since they were designed from the very beginning as a set of interrogations that should, hopefully, create a picture of customer reactions to the top-5 most frequent scandals in which the celebrities may fall: infidelity, drug abuse, rape, theft or murder.

The participants were asked to say how likely is to stop purchasing a certain product if its endorser would have been accused of the above mentioned felonies, the goal being to observe if there are any scandals that may influence more the customer purchase intentions than others. As surprising as it may be, apparently, the results suggest that indeed, there are some crimes that the general public is not willing to forget.

When asked about infidelity of the endorser, a cumulative percent of $71,3 \%$ of the respondents replied that they are "strongly disagreeing" or "disagreeing" the fact that they would stop buying the endorsed product. The percentage tends to become smaller and smaller on a inverse relationship with the gravity of the accusations brought to the endorser: $70,3 \%$ of the participants chose the same options in the case of the drugs related accusations, compared to $44,6 \%$ in the case of rape, 63,4 in the case of theft and only 38,6 in the case of murder.

On the other hand, even when dealing with really bad accusations, such as murder or rape, people tend to be capable of distinguishing between the celebrity and the endorsed product: only $27,7 \%$ of the respondents ticked "strongly agree" or "agree" when asked if they will stop buying a product endorsed by a celebrity accused of crime, the percentage being even smaller (18.8\%) when the endorser is facing a rape accusation. Such conclusions may suggest that indeed, some people may experience shifts in their purchase intentions when the endorser of the products had done some really bad crimes - however, the data is really inconclusive 
to put such a diagnosis and moreover, it is still clear that the great majority will still not be influenced by the scandal when deciding to buy their favorite brand.

Rate the following questions, 5 representing "strongly agree" and 1 "strongly disagree" -I would stop buying a product endorsed by a celebrity accused of infidelity

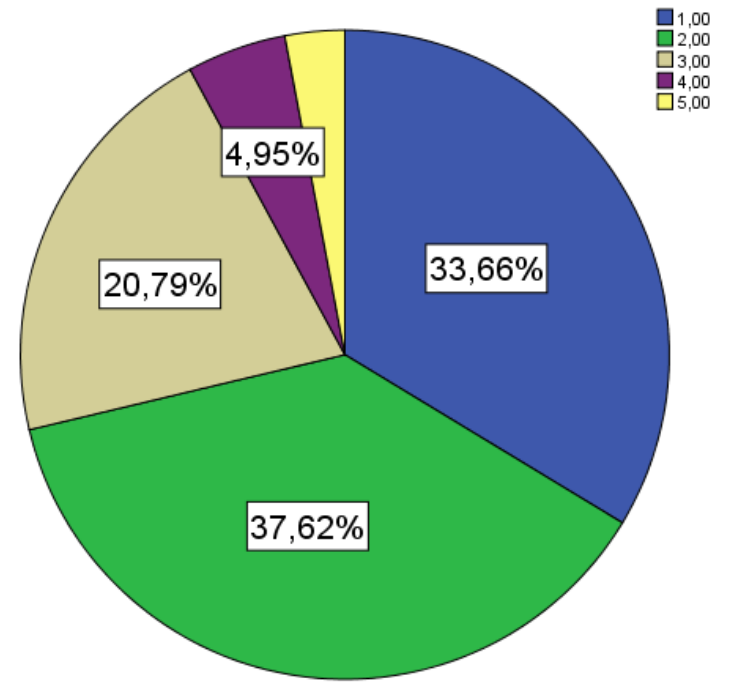

Rate the following questions, 5 representing "strongly agree" and 1 "strongly disagree" - I would stop buying a product endorsed by a celebrity accused of murder

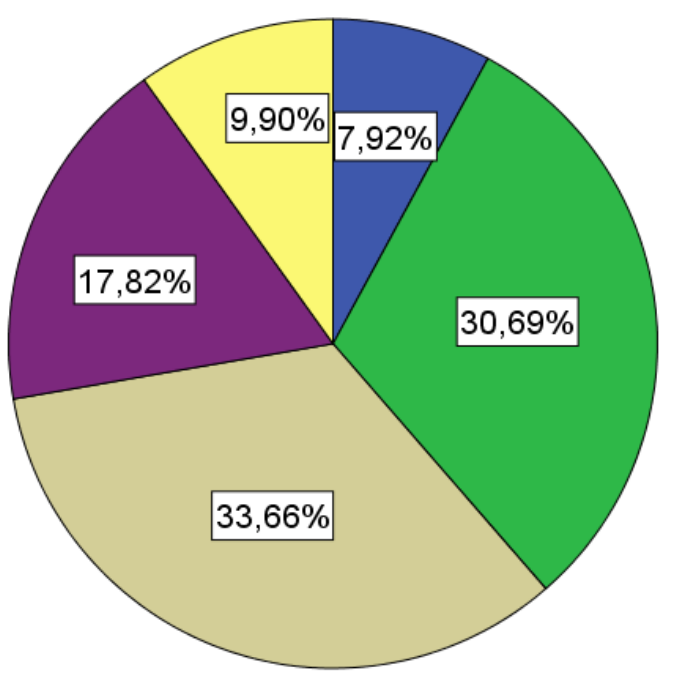

Figure 1.1. Differences between scandals of infidelity and murder in terms of customer purchase intentions

\section{Testing hypotheses and relationships}

H1: Are there any differences between males and females in terms of changing the attitude towards a brand when a scandal arises?

In order to be able to come up with an answer to this question, an Independent Sample T-Test had to be carried on, its goal being to see if and how gender is influencing the reaction to scandals towards the brand endorsed.

Table 2.9. Group Statistics

\begin{tabular}{|l|l|l|l|}
\hline \multicolumn{1}{|c|}{ Please select your gender } & $N$ & Mean & Std. Deviation \\
\hline Rate the following1,00 & 49 & 2,2245 & 1,10426 \\
questions, 5 representing \\
"strongly agree" and 12,00 \\
"strongly disagree" / I \\
change my attitude \\
$\begin{array}{l}\text { towards a brand if the } \\
\text { celebrity used is involved } \\
\text { in a scandal. }\end{array}$
\end{tabular}


Table 2.10. Group Statistics

\begin{tabular}{|l|l|}
\hline \multicolumn{1}{|c|}{ Please select your gender / } & Std. Error Mean \\
\hline $\begin{array}{l}\text { Rate the following questions, 51,00 } \\
\text { representing "strongly agree" and } 1\end{array}$ & 15775 \\
"strongly disagree" / I change my2,00 & 15422 \\
$\begin{array}{l}\text { attitude towards a brand if the celebrity } \\
\text { used is involved in a scandal }\end{array}$ & \\
\hline
\end{tabular}

Table 2.11. Independent Samples Test

\begin{tabular}{|c|c|c|c|}
\hline & $\begin{array}{l}\text { Levei } \\
\text { Varia } \\
\end{array}$ & for Equality of & $\begin{array}{l}\text { t-test for } \\
\text { Equality of } \\
\text { Means }\end{array}$ \\
\hline & $\mathrm{F}$ & Sig. & t \\
\hline $\begin{array}{l}\text { Rate the followingEqual variances assumed } \\
\text { questions, } 5 \text { representing } \\
\text { "strongly agree" and 1Equal variances not } \\
\text { "strongly disagree" / Iassumed } \\
\text { change my attitude } \\
\text { towards a brand if the } \\
\text { celebrity used is involved } \\
\text { in a scandal }\end{array}$ & 000 & 989 & $\begin{array}{r}-, 377 \\
-, 377\end{array}$ \\
\hline
\end{tabular}

Table 2.12. Independent Samples Test

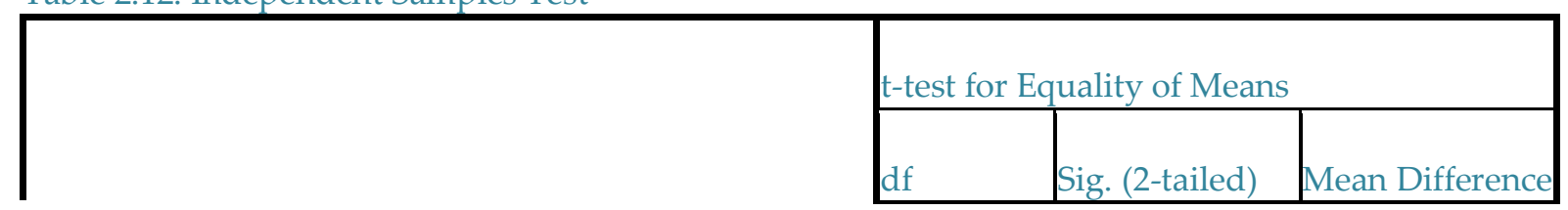




\begin{tabular}{|l|l|l|l|}
\hline & & & \\
\hline $\begin{array}{l}\text { Rate the followingEqual variances assumed } \\
\text { questions, } 5 \text { representing } \\
\text { "strongly agree" and 1Equal variances not } \\
\text { "strongly disagree" / Iassumed } \\
\text { change my attitude towards } \\
\text { a brand if the celebrity used } \\
\text { is involved in a scandal }\end{array}$ & 98,723 &, 707 & -,08320 \\
\hline
\end{tabular}

Table 2.13. Independent Samples Test

\begin{tabular}{|c|c|c|}
\hline & \multicolumn{2}{|c|}{ t-test for Equality of Means } \\
\hline & \multirow{2}{*}{$\begin{array}{ll}\text { Std. } & \text { Error } \\
\text { Difference } & \\
\end{array}$} & $\begin{array}{l}95 \% \text { Confidence } \\
\text { Interval of the } \\
\text { Difference }\end{array}$ \\
\hline & & Lower \\
\hline $\begin{array}{l}\text { Rate the following questions, 5Equal variances assumed } \\
\text { representing "strongly agree" } \\
\text { and } 1 \text { "strongly disagree" / IEqual variances not assumed } \\
\text { change my attitude towards a } \\
\text { brand if the celebrity used is } \\
\text { involved in a scandal }\end{array}$ & 22066 & $\begin{array}{l}-, 52104 \\
-, 52096\end{array}$ \\
\hline
\end{tabular}

Table 2.14. Independent Samples Test

\begin{tabular}{|c|c|}
\hline & $\begin{array}{l}\text { t-test for Equality of } \\
\text { Means }\end{array}$ \\
\hline & $\begin{array}{ll}95 \% & \text { Confidence } \\
\text { Interval of the } \\
\text { Difference }\end{array}$ \\
\hline & Upper \\
\hline $\begin{array}{l}\text { Rate the following questions, 5Equal variances assumed } \\
\text { representing "strongly agree" and } 1 \\
\text { "strongly disagree" / I change myEqual variances not assumed } \\
\text { attitude towards a brand if the celebrity } \\
\text { used is involved in a scandal }\end{array}$ & $\begin{array}{l}, 35463 \\
, 35456\end{array}$ \\
\hline
\end{tabular}


After carrying on the T-test, no clear differences could be observed between males and females in what concerns the attitude towards a brand when the celebrity is involved in a scandal. Since p(sig. 2-tailed) is bigger than 0,05, it is clear that the reaction towards scandals and endorser are not influenced by gender, no such statistical evidence being found. In other words, males and females are having similar reactions to scandals, both of them being very difficult to influence by a celebrity scandal when it comes to purchasing things.

H2: Are there any differences between males and females in terms of treating differently the foreign and the local celebrities once a scandal arises?

In order to be able to give an answer to this question, a Crosstab Test had to be carried on, both variables analyzed (gender and q5 - concerning the attitude towards scandals for foreign and local celebrities) being nominal. The results are presented below:

\section{Table 2.15 Crosstabs}

Please select your gender * Please consider a Romanian and a foreign celebrity, endorsing two products that you normally buy and falling into some really disturbing scandals for you. Which of the following statements describe best your attitude - Crosstabulation

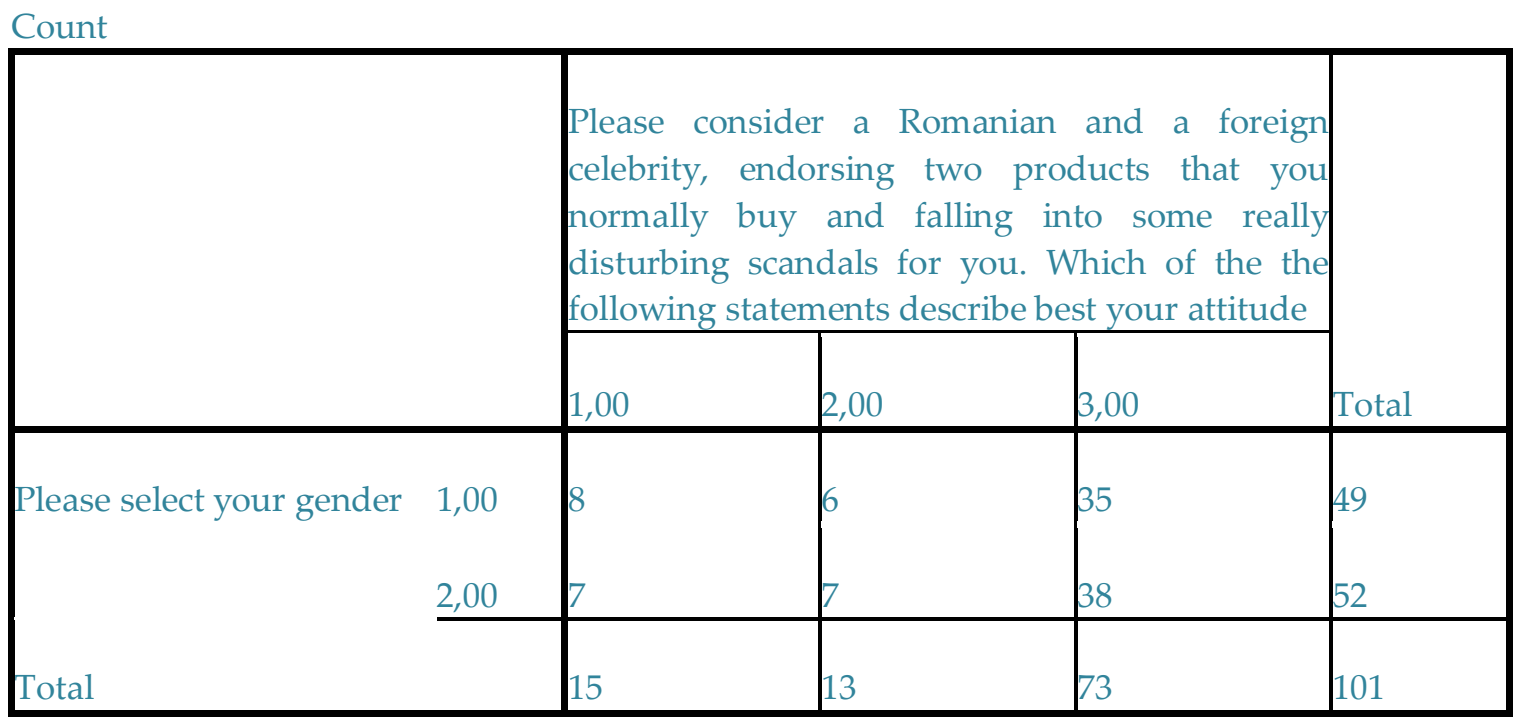

Table 2.16. Chi-Square Tests

\begin{tabular}{|l|l|l|l|}
\hline & & & $\begin{array}{l}\text { Asymp. Sig. (2- } \\
\text { sided) }\end{array}$ \\
\hline Pearson Chi-Square & $178^{\mathrm{a}}$ & 2 & 915 \\
Likelihood Ratio & 178 & 2 & 915 \\
\hline Linear-by-Linear & & df & 759 \\
\hline Association & 094 & 1 &
\end{tabular}




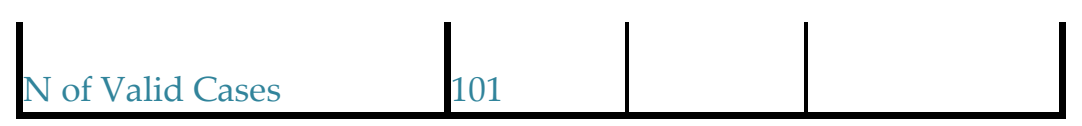

After the crosstab test, the $\mathrm{p}$ appears to be $\mathrm{P}=0,91$, a score which clearly suggest that the values are not statistically significant. In conclusion, gender does not influence potential differences in treating local and foreign celebrities, both genders treating them relatively the same. Both males and females seem to have the same attitude when it comes to a similar scandal, no matter if the protagonist is a Romanian star (example: Adrian Mutu) or a foreign, world-class one (like Tiger Woods).

H3: Is there any relationship between the viewership of celebrity news and the reactions to various types of scandals (infidelity, drugs, rape, theft or crime) in which the celebrities are falling?

The correlations test is used when both of the variables to be analyzed (in the present case, the viewership of the celebrity news and reaction to each type of accusation) are intervals. The present test wanted to check if people are tending to treat differently (in terms of buying behavior, of course) the various accusations which a celebrity may face due to the prolonged exposure to celebrity news. In other words, will people who watch intense mundane news be more inclined to stop purchasing a certain product when an infidelity, drug, rape, theft or murder accusation appears?

\begin{tabular}{|c|c|c|c|c|c|c|}
\hline & \begin{tabular}{|l} 
I would \\
stop \\
buying a \\
product \\
endorsed \\
by a \\
celebrity \\
accused of \\
infidelity.
\end{tabular} & \begin{tabular}{|l|} 
I would \\
stop \\
buying a \\
product \\
endorsed \\
by a \\
celebrity \\
involved \\
accused of \\
drug \\
issues
\end{tabular} & $\mid \begin{array}{l}\text { I would } \\
\text { stop } \\
\text { buying a } \\
\text { product } \\
\text { endorsed } \\
\text { by } \\
\text { celebrity } \\
\text { accused of } \\
\text { rape. }\end{array}$ & $\mid \begin{array}{l}\text { I would } \\
\text { stop } \\
\text { buying a } \\
\text { product } \\
\text { endorsed } \\
\text { by } \\
\text { celebrity } \\
\text { accused of } \\
\text { theft. }\end{array}$ & $\begin{array}{l}\text { I would } \\
\text { stop } \\
\text { buying a } \\
\text { product } \\
\text { endorsed } \\
\text { by a } \\
\text { celebrity } \\
\text { accused of } \\
\text { crime. }\end{array}$ & $\begin{array}{l} \\
\text { I follow } \\
\text { the } \\
\text { celebrity } \\
\text { news } \\
\text { because I } \\
\text { care about } \\
\text { their } \\
\text { personal } \\
\text { life. }\end{array}$ \\
\hline \multirow{2}{*}{$\begin{array}{l}\text { I would stopPearson } \\
\text { buying a productCorrelation } \\
\text { endorsed by a } \\
\text { celebrity accusedSig. (2-tailed) } \\
\text { of infidelity } \\
\qquad \\
\mathrm{N}\end{array}$} & 1 & $\begin{array}{l}871^{* *} \\
, 000\end{array}$ & $\begin{array}{l}719^{* *} \\
000\end{array}$ & $\begin{array}{l}789^{* *} \\
000\end{array}$ & $\begin{array}{l}, 711^{* *} \\
, 000\end{array}$ & $\begin{array}{l}277^{* *} \\
005\end{array}$ \\
\hline & 101 & 101 & 101 & 101 & 101 & 101 \\
\hline $\begin{array}{l}\text { would stopPearson } \\
\text { buying a productCorrelation }\end{array}$ & $871^{* *}$ & 1 & $729^{* * *}$ & $801^{* *}$ & $697^{* *}$ & $264^{* *}$ \\
\hline $\begin{array}{l}\text { endorsed by a } \\
\text { celebrity involvedSig. (2-tailed) } \\
\text { accused of drug } \\
\text { issues }\end{array}$ & $\begin{array}{l}000 \\
101\end{array}$ & 101 & $\begin{array}{l}000 \\
101\end{array}$ & $\left\{\begin{array}{l}000 \\
101\end{array}\right.$ & $\begin{array}{l}000 \\
101\end{array}$ & $\begin{array}{l}008 \\
101\end{array}$ \\
\hline
\end{tabular}




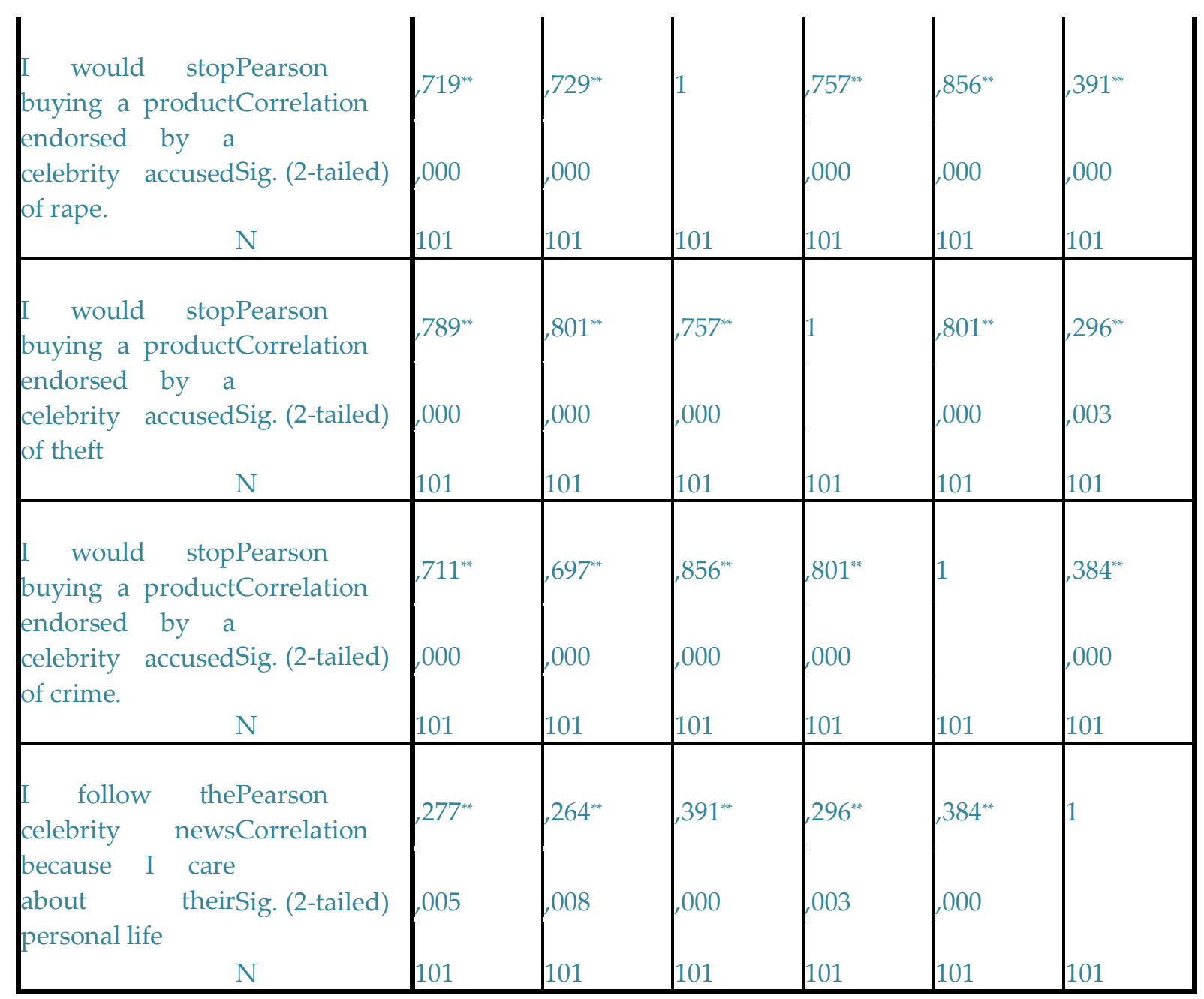

When trying to analyze the possible relationship between celebrity news viewership and the decision of not buying a product due to the fact that its endorser is accused of infidelity, drug usage, rape, theft or murder, the data appear to be significant, all of them having values under the maximum level of 0,05 $(0,005$ for infidelity, 0,008 for drug usage, 0 for rape, 0,003 for theft and 0 for murder).

The correlation levels are however relatively small such as to assume a direct strong correlation between the viewership of news and the decision of not buying due to one of the accusations: 0,277 for infidelity, 0,264 for drug usage, 0,391 for rape, 0,296 for theft and 0,384 for murder. While the data do not suggest a strong correlation, it is still very possible that the celebrity news may influence their viewers when it comes to shifting customer purchase intentions due to various accusations.

H4: Is the viewership of celebrity news related to the shifting of customers' attitudes towards the endorsed brand, once a scandal implying its endorser arises?

Table 2.18. Correlations

\begin{tabular}{|l|l|l|}
\hline & $\begin{array}{l}\text { follow the } \\
\text { celebrity news change my } \\
\text { because I care }\end{array}$ \\
$\begin{array}{l}\text { about attitude } \\
\text { personal life }\end{array}$ & if the celebrity \\
\hline
\end{tabular}




\begin{tabular}{|l|l|l|}
\hline & & $\begin{array}{l}\text { used is involved } \\
\text { in a scandal }\end{array}$ \\
\hline $\begin{array}{l}\text { I follow the celebrity newsPearson Correlation } \\
\text { because I care about their } \\
\text { personal life }\end{array}$ & 1 & $392^{* *}$ \\
\hline Sig. (2-tailed) & 101 & 1000 \\
\hline $\begin{array}{l}\text { I change my attitudePearson Correlation } \\
\text { towards a brand if the } \\
\text { celebrity used is involvedSig. (2-tailed) } \\
\text { in a scandal }\end{array}$ & 000 & 1 \\
\hline
\end{tabular}

\section{**. Correlation is significant at the 0.01 level (2-tailed).}

The significance level sig. (2-tailed) is 0, lower than 0,05 (the level from which we can assume that in 95\% the relationship is not due to chance), this being an excellent news. However, a correlation level of 0,392 is relatively small such as to assume the hypothesis that indeed, people who watch celebrities news are tending to change their customer purchase intentions once a scandal arises, in a degree more visible than those who don't follow these kind of news.

The score does not exclude such hypothesis, being at the end of the day, a score corresponding to a positive correlation. However, the result is still below 0,5, the level from which we can assume a relevant positive correlation. It remains a possible hypothesis, which may become a point of further research, but it cannot be fully verified at this point, with the present data.

H5: Are there any education-related differences in terms of reacting to scandals from a consumer purchase intention point of view?

Using a One-way ANOVA test, two variables (a nominal one with more than two groups and an interval) can be tested for differences. The idea behind this test was to see if education has any influence over the consumer purchase intention, once a scandal is occurring - in other words, to check if more educated people tend to have a smaller shift in their in their purchase intention compared to the less educated ones.

\section{Table 2.19. Descriptives}

Rate the following questions, 5 representing "strongly agree" and 1 "strongly disagree" / I change my attitude towards a brand if the celebrity used is involved in a scandal

\begin{tabular}{|c|c|c|c|c|c|c|}
\hline & \multirow[b]{2}{*}{$\mathrm{N}$} & \multirow[b]{2}{*}{ Mean } & \multirow[b]{2}{*}{ Std. Deviation } & \multirow[b]{2}{*}{ Std. Error } & \multicolumn{2}{|c|}{$\begin{array}{l}95 \% \text { Confidence Interval fo } \\
\text { Mean }\end{array}$} \\
\hline & & & & & Lower Bound & Upper Bound \\
\hline 1,00 & 3 & 2,6667 & 1,15470 & 66667 & -2018 & 5,5351 \\
\hline
\end{tabular}




\begin{tabular}{|l|l|l|l|l|l|l|}
2,00 & 23 & 2,0870 & 1,12464 & 23450 & 1,6006 & 2,5733 \\
\hline 3,00 & 41 & 2,1463 & 1,08538 & 16951 & 1,8038 & 2,4889 \\
4,00 & 34 & 2,5000 & 1,10782 & 18999 & 2,1135 & 2,8865 \\
\hline Total & 101 & 2,2673 & 1,10355 & 10981 & 2,0495 & 2,4852 \\
\hline
\end{tabular}

Table 2.20. Descriptives

Rate the following questions, 5 representing "strongly agree" and 1 "strongly disagree" / I change my attitude towards a brand if the celebrity used is involved in a scandal

\begin{tabular}{|l|l|l|}
\hline \multirow{2}{*}{} & & \\
& Minimum & Maximum \\
\hline 1,00 & 2,00 & 4,00 \\
\hline 2,00 & 1,00 & 5,00 \\
\hline 3,00 & 1,00 & 5,00 \\
\hline 4,00 & 1,00 & 5,00 \\
\hline Total & 1,00 & 5,00 \\
\hline
\end{tabular}

Table 2.21. ANOVA

Rate the following questions, 5 representing "strongly agree" and 1 "strongly disagree" / I change my attitude towards a brand if the celebrity used is involved in a scandal

\begin{tabular}{|l|l|l|l|l|l|}
\hline & Sum of Squares & df & Mean Square & F & Sig. \\
\hline Between Groups & 3,667 & 3 & 1,222 & 1,004 & 395 \\
\hline Within Groups & 118,115 & 97 & 1,218 & & \\
\hline Total & 121,782 & 100 & & & \\
\hline
\end{tabular}


No statistical evidence could be found in what concerns the hypothesis of education influencing the customer purchase intention when it comes to a product endorser falling into a scandal. Since the $p=0,395$ is bigger than the maximum limit of 0,05 , we cannot say that education is influencing in any manner the attitude towards a brand when its endorser falls into a scandal. For those that do change their buying behavior when faced with such a scandal, this appears to be more an emotional decision, rather than a rational one.

H6: Are there any education-related differences in terms of reacting to various types of scandals (infidelity, drugs, rape, theft or crime) in which the celebrities are falling?

Similarly to the above analyzed hypothesis, H6 is trying to focusing on each accusation brought to celebrities, rather than on the larger term of "scandals". The idea behind the analysis was to see if some big felonies, such as rape or murder, are capable of disturbing more or less the educated people compared with the less educated ones. For the purposes of this test, the one-way ANOVA was also used, since we are talking about a variable with more than two groups and five intervals.

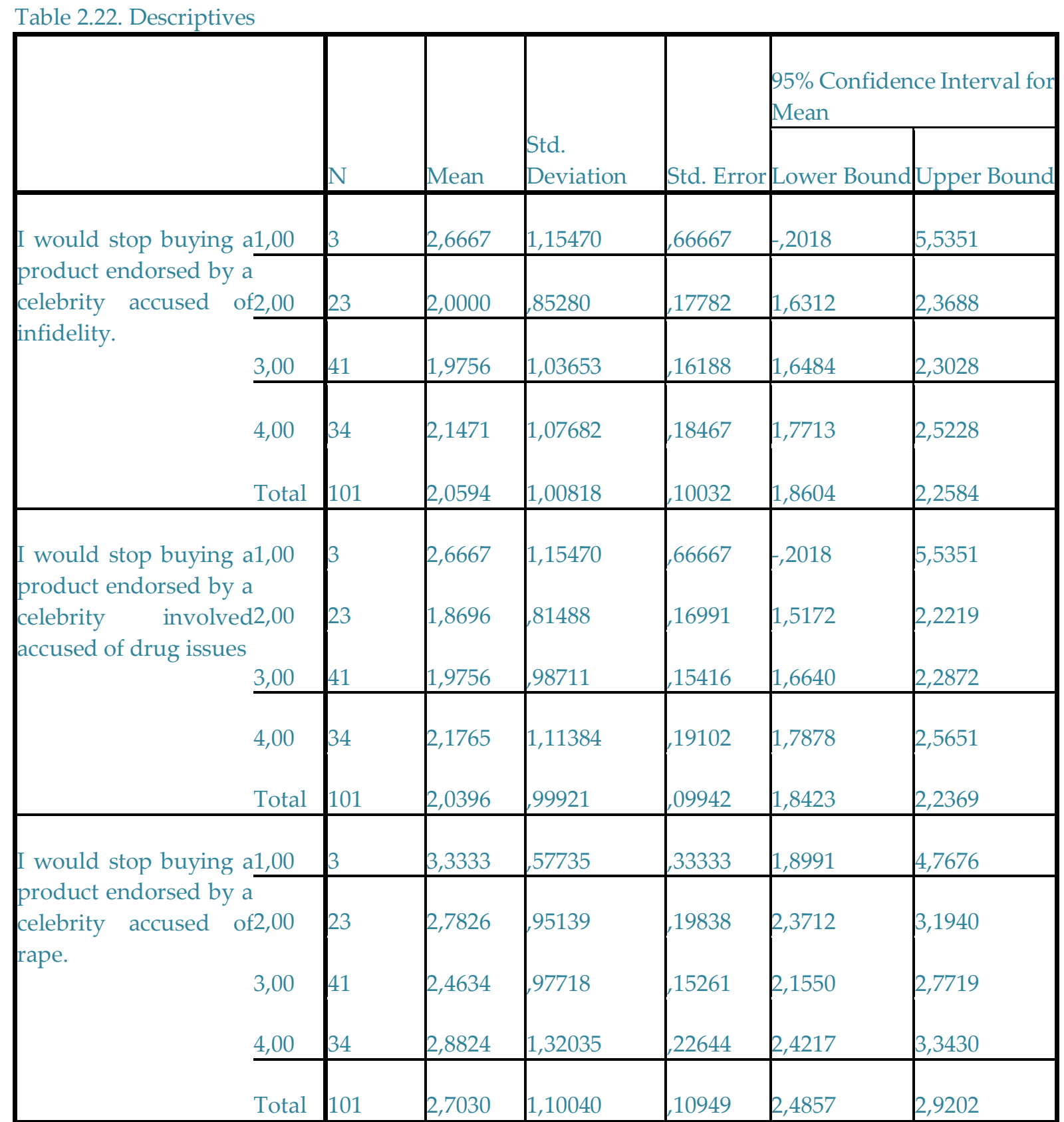




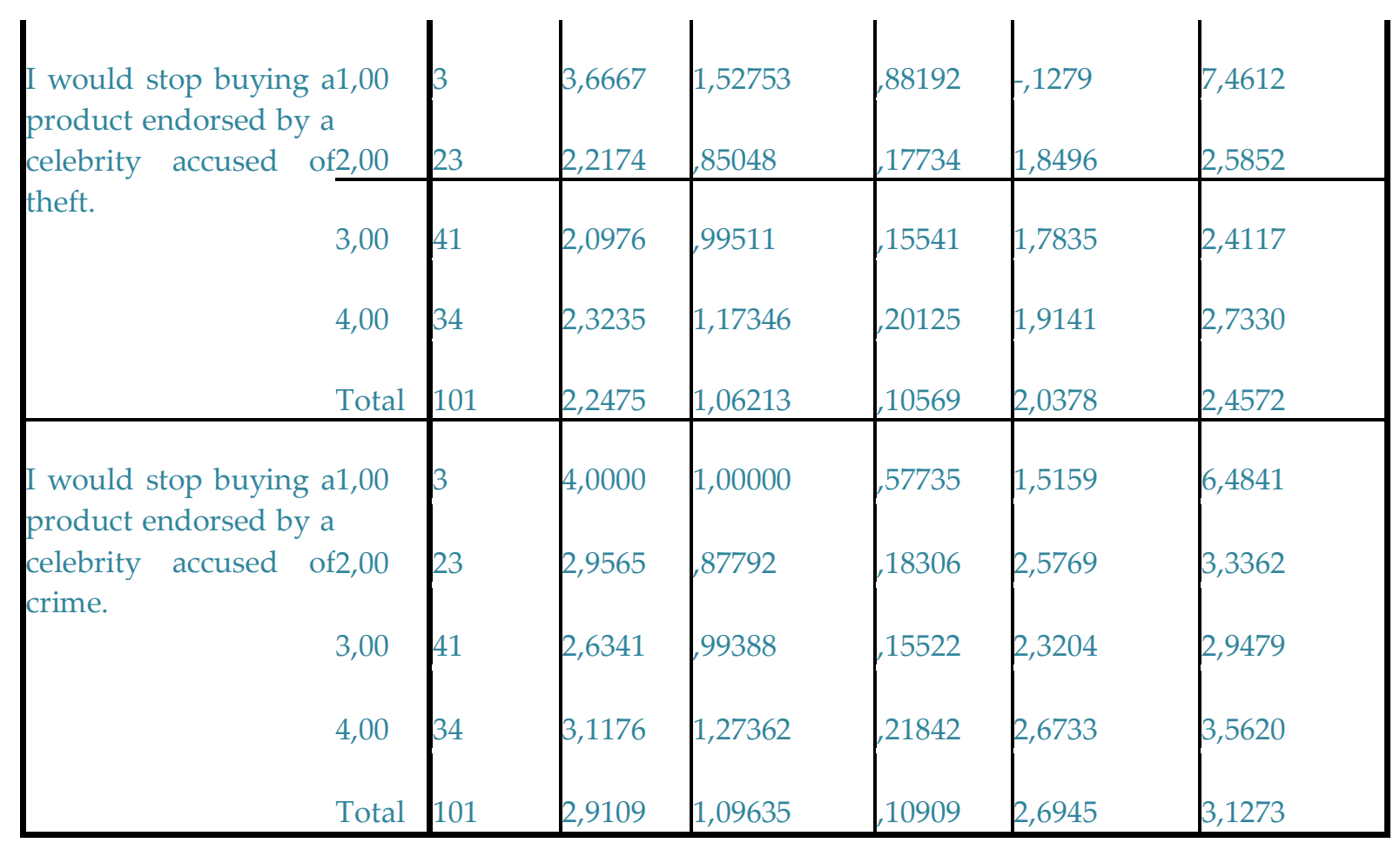

Table 2.23. Descriptives

\begin{tabular}{|c|c|c|}
\hline & Minimum & Maximum \\
\hline $\begin{array}{l}\text { I would stop buying a product endorsed by a1,00 } \\
\text { celebrity accused of infidelity. }\end{array}$ & 2,00 & 4,00 \\
\hline 2,00 & 1,00 & 4,00 \\
\hline 3,00 & 1,00 & 5,00 \\
\hline 4,00 & 1,00 & 5,00 \\
\hline Total & 1,00 & 5,00 \\
\hline $\begin{array}{l}\text { I would stop buying a product endorsed by a1,00 } \\
\text { celebrity involved accused of drug issues }\end{array}$ & 2,00 & 4,00 \\
\hline 2,00 & 1,00 & 3,00 \\
\hline 3,00 & 1,00 & 5,00 \\
\hline 4,00 & 1,00 & 5,00 \\
\hline Total & 1,00 & 5,00 \\
\hline 1,00 & 3,00 & 4,00 \\
\hline
\end{tabular}




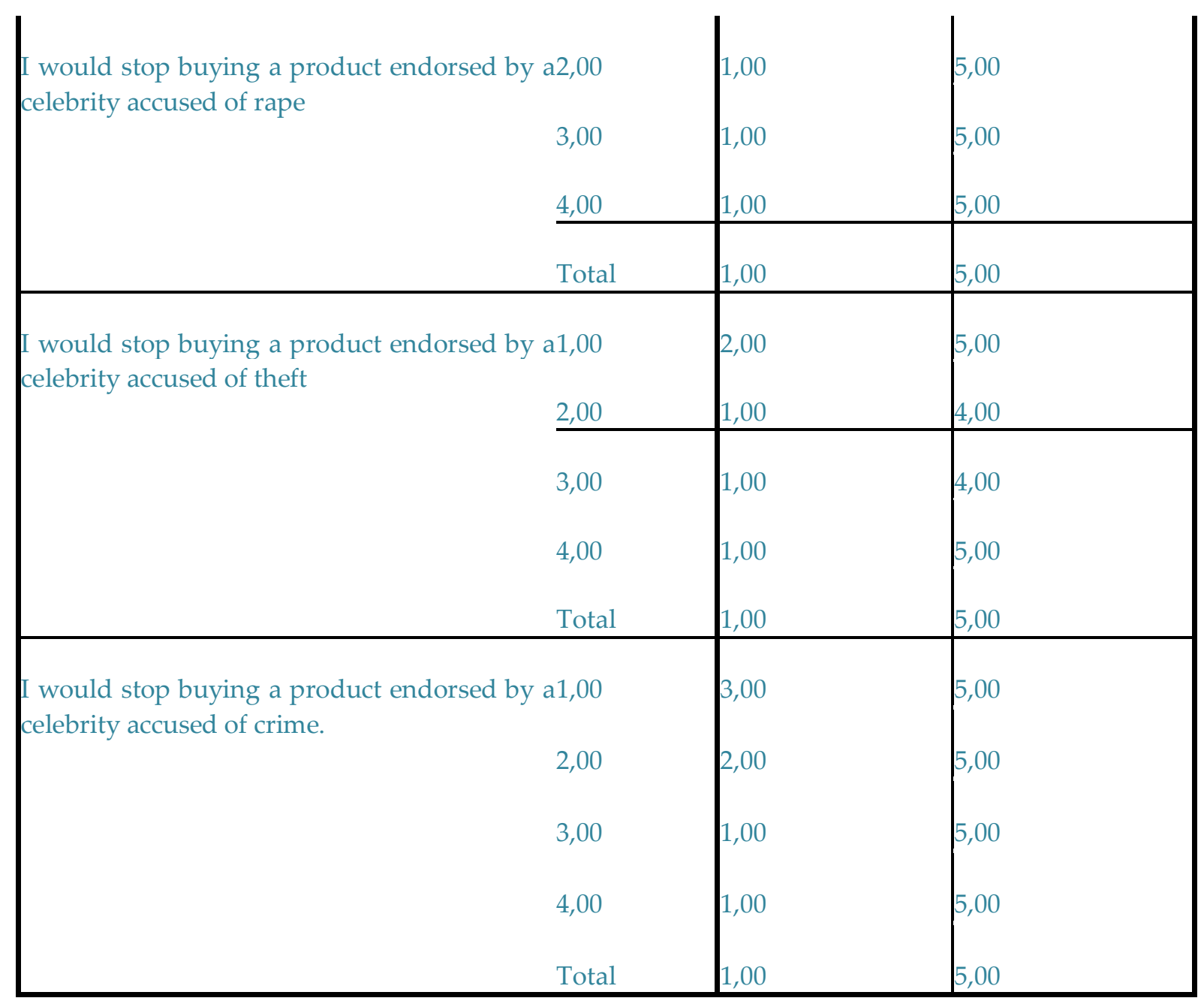

Table 2.24. ANOVA

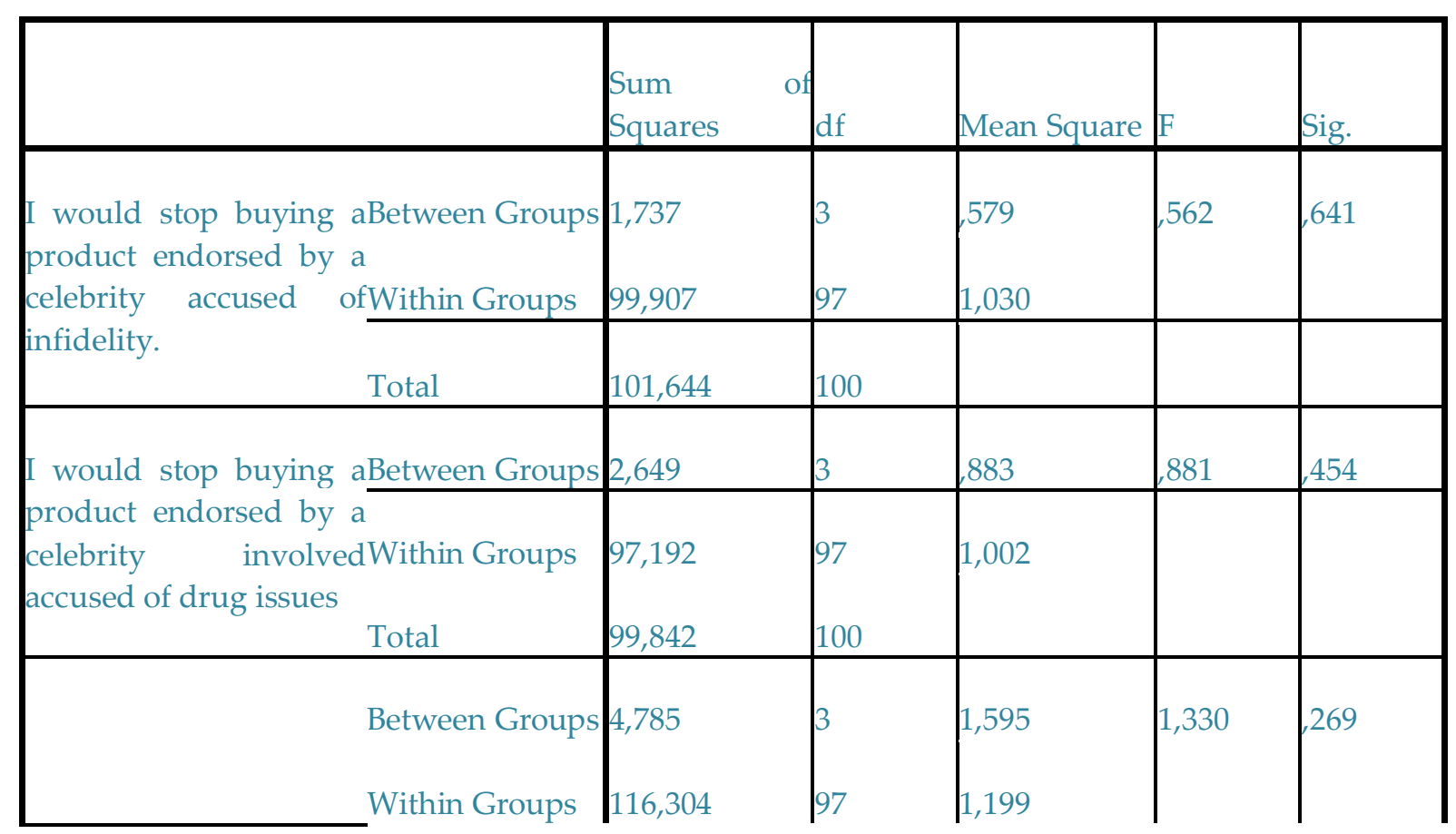




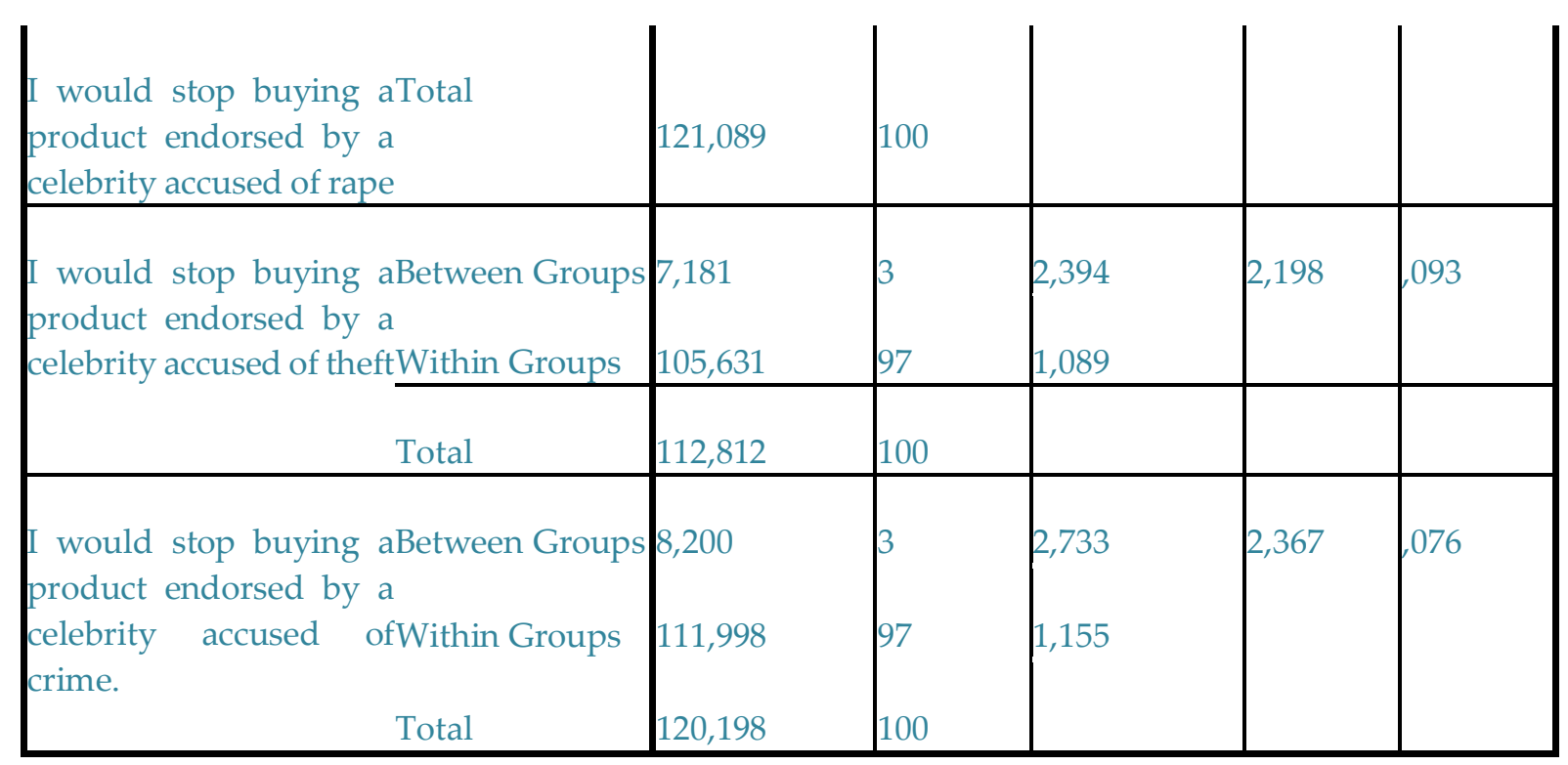

No statistical evidence could be found in what concerns the hypothesis of education influencing the reaction to various types of scandals (infidelity, drugs, rape, theft or murder), all the p's being far bigger than the maximum limit of 0,05 ( 0,64 for infidelity, 0,45 for drugs, 0,269 for rape, 0,093 for theft and 0,076 for murder). In consequence, even if surprisingly, the education level of the respondents has nothing to do with their actions towards the brand, once a scandal concerning its endorser appears. This conclusion remains the same no matter if we talk about a really serious accusation, like a murder one, or a rather easier one, such as infidelity.

\section{Conclusions}

This study supports the theory of Money, Shimp and Sakano (2006), observing that indeed, advertisers should not hurry up to terminate the agreements with the celebrities the second day after they get into a problem and are faced with negative publicity.

As remembered, the study had departed from three main research goals: to observe if there is there a link between the occurrence of scandals in the lives of the celebrities and the customers buying intentions, to check if people are having different reactions in terms of consumer purchasing decision when it comes to different negative actions of the celebrities and to observe if Romanian youngsters - the target group of this study - are treating Romanian celebrities and foreign ones in the same ways once the scandal is occurring in terms of buying decisions.

The results were surprising, suggesting that the inhabitants of Bucharest don't really care about celebrity endorsing when deciding about buying products or services. Concerning the first research objective, the findings prove that while indeed Romanians are eager to find out more about celebrities' lives and the inherent scandals associated with their existence, the occurrence of such problems are seen more like "entertainment" rather than influencers in the customer purchase decision. More than $60 \%$ of the respondents declared that they don't change their buying behavior because of a scandal in which a product endorser may fall in and almost $64 \%$ of them said that they don't see any reason for which the management of a company should terminate a contract with a troubled endorser. These results have to be correlated with the fact that, at least on the public questioned, celebrity endorsement does not seem to work very good as an appeal. Only $46 \%$ of the respondents declared that they buy products endorsed by celebrities, the percentage of those unaware about this (almost $40 \%$ ) being striking and suggesting that celebrities and celebrity endorsement is not as powerful here as it abroad.

Furthermore, when trying to analyze the possible differences in treating local and foreign "fallen stars" the respondents seem not to care about the fame of the celebrity or its place of origin. The results present extremely similar values to a similar situation in which Tiger Woods (a world-class celebrity) and Adrian Mutu (the former captain of the national football team) could have been implied. The fact that people are treating 
celebrities in the same way is also underlined by the fact that $72,3 \%$ of the respondents had specifically declared that, in the same situation (referring to a scandal), they will have the same attitude towards the brand endorsed by the celebrities, no matter if the celebrity was Romanian or not.

Finally, the last research objective presents some curious values, the number of those declaring that they will stop buying the product if its endorser is accused of a certain felony tending to increase on a direct relationship with the gravity of the felony of which the celebrity was accused ( $8 \%$ for infidelity, $8 \%$ for drug issues, $12,9 \%$ for theft, $17,9 \%$ for rape and $27,7 \%$ for murder). From this point of view, the results seem closer with those obtained by Bailey (2007), who discovered that people have different reactions and experience different degrees of attitude changing, depending on the scandal in which the endorser may provoke. Unlike Bailey's case however, the great majority of the respondents from the present survey will still continue to purchase their favorite products, no matter of the accusation brought to the endorser, proving once again that scandals don't really influence customer purchase intentions.

Furthermore, several hypotheses have been built, in order to check if these results are somehow related to the gender of the respondents or to their education level (for this purpose, people were asked to tick their last level of education, from four pre-defined options). According with the data obtained, there are similar results in what concerns the customer purchase intentions when a scandal is occurring both for males and females, a similar result being noticed in the case of the equal treatment between local and foreign celebrities. Clearly, gender is not a variable capable to influence the attitude towards scandals in celebrity endorsement.

When it comes about education, the results are also clear - no matter if we are talking about elementary school graduates or people with post-graduate degrees, the impact of scandals in their customer purchase intention in the same: almost none. The results obtained are valid therefore for pretty much all the sample analyzed, no matter their instruction or gender.

Finally, quite surprising, the data obtained is suggesting than viewership of mundane news is not creating a predisposition towards being influenced by scandals when creating the customer buying intention. People who follow the celebrities' lives closely and are really interested in the daily aspects of their existence presented similar results with those how are not doing this, in terms of reaction towards brands when their endorsers enter into scandals.

To conclude, there was no statistical evidence such as to support the idea that the consumer purchase intention is influenced by celebrity endorsers' scandals, the people of Bucharest being relatively indifferent to such events from a buying decision perspective. Also, when it comes to the scandals of local and foreign celebrities, the respondents seemed to have similar views, proving that no matter how big or important the celebrity is, the local customer will pretty much have the same attitude towards the brands endorsed, when that celebrity will do a bad thing.

The findings of this paper will fill a gap in the Romanian customer behavior analysis and should raise some question marks to both the practitioners and the scholars in the field. Primarily, the great benefit of the study is the fact that it clearly demonstrated that, at least locally, advertisers should not hurry up to terminate agreements with stars, once a scandal is occurring in their lives. However, on a secondary level, the fact that people are so indifferent to scandals may suggest also that celebrity endorsement is not really the most efficient appeal for the analyzed population and further research could take into account this hypothesis.

\section{References}

Agrawal, J., Kamakura, W.A. (1995) The Economic Worth of Celebrity Endorsers: An event Study Analysis, Journal of Marketing 59(3), pp. 56-62, Business Source Complete, EBSCOhost, viewed 20 April 2014.

Alexander, R. (1965) Marketing definitions, Chicago: American Marketing Associations

American Marketing Association (2010) Resource Library. Available from: www.marketingpower. com /layouts/dictionary.aspx, viewed 12 April 2013.

Armstrong, G., Kotler, P. (2000) Marketing: An introduction, Upper Saddle River, New Jersey: Prentice Hall. 
Bailey, A. (2007) Public Information and Consumer Skepticism Effects on Celebrity Endorsements: Studies among Young Consumers, Journal Of Marketing Communications, 13(2), pp. 85-107, Business Source Complete, EBSCOhost, viewed 22 April 2014.

Barringer, B.R., Ireland, R.D. (2010) Entrepreneurship, Successfully Launching New Ventures, 3rd Edition. New Jersey: Pearson.

Bedinger, B., (1993) Copy Work Shop Work Book, Chicago: The Copy Workshop

Belch, G., Belch M. (2012) Advertising and Promotion. An Integrated Marketing Communication Perspective. New York: McGraw-Hill/Irwin

Belloni, M., Kit, B. (2014) Charlie Sheen No-Shows Delay 'Anger Management' Production (Exclusive), Hollywood Reporter, electronic resource, available at http://www.hollywoodreporter .com/live-feed/charliesheen-no-shows-delay-687040, viewed 15 April 2014

Belson, K., Pilon, M. (2012) Armstrong Is Dropped by Nike and Steps Down as Foundation Chairman, New York Times, Electronic Edition, available at http://www.nytimes.com/2012 /10/18/sports/cycling/lancearmstrong-dropped-by-nike-steps-down-as-chairman-of-his-charity .html?pagewanted=all, accessed 19 April 2013

Blackford, B., Gentry, J., Harrison, R., \& Carlson, L. (2011) The Prevalence and Influence of the Combination of Humor and Violence in Super Bowl Commercials, Journal Of Advertising, 40(4), pp. 123-134, Business Source Complete, EBSCOhost, viewed 16 April 2014.

Brown, T.J., Rothschild, M.L. (1993) Reassessing the Impact of Television Advertising Clutter, Journal of Consumer Research, 20(1), pp. 138-146, Business Source Complete, EBSCOhost, viewed 18 April 2014.

Carone, C., (2011) Earn a Spot in Your Customer's "Final Four" Disclaimer: Yes, it's still October, not to be confused with March Madness, Xerox Blogs (online) Available from http://realbusinessatxerox.blogs.xerox.com/2011/10/10/earn-a-spot-in-your-customer\%E2\%80\%99s $\%$ E2\%80\%9Cfinal-four\%E2\%80\%9D-disclaimer-yes-it\%E2\%80\%99s-still-october-not-to-be-confused-withmarch-madness/\#.UWdAfqJTJZA, viewed 12 April 2014

Carrillat, F., d'Astous, A., \& Lazure, J. (2013) For Better, for Worse?: What to Do When Celebrity Endorsements Go Bad, Journal Of Advertising Research, 53(1), pp. 15-30, Business Source Complete, EBSCOhost, viewed 18 April 2014.

Chandon, J., Maazoul, M., \& Khalbous, S. (2013) Effets de l'encombrement et de la presence de marques concurrentes sur la memorisation des spots publicitaires (French), Revue Francaise du Marketing, 244(245), pp. 9-26,, Business Source Complete, EBSCOhost, viewed 20 April 2014.

Charry, K., \& Demoulin, N. (2012) Behavioural evidence for the effectiveness of threat appeals in the promotion of healthy food to children, International Journal Of Advertising, 31(4), pp. 773-794, Business Source Complete, EBSCOhost, viewed 19 April 2014.

Cohen J.B., Golden, E. (1972) Informational Social Influence and Product Evaluation, Journal of Applied Psychology, 56(2), pp. 54-59, Business Source Complete, EBSCOhost, viewed 19 April 2014.

Cravens, D.W., Piercy, N.F. (2013) Strategic Marketing, 10th Edition, Singapore: McGraw-Hill Education.

Creswell, J.W. (2013) Research design: Qualitative, quantitative, and mixed methods approaches, Thousands Oaks: Sage Publications 
Czinkota, M.R. (ed.) (2000) Marketing: Best practices, Orlando: The Dryden Press

D'Onofrio, M. (1999) Web, e-mail surveys cheap but have disadvantages, Advertising Age's Business Marketing, 84(6), p. 17, Business Source Complete, EBSCOhost, viewed 20 April 2014.

English Dictionary (2002), Glasgow: HarperCollins Publishing

Franchising World (2002) Dave Thomas, Wendy's Founder, Passes Away 2002, 34(2), p. 61, Business Source Complete, EBSCOhost, viewed 19 April 2014.

Friedman, H.H., \& Friedman, L. (1979) Endorser Effectiveness by Product Type, Journal of Advertising Research, 19(1), pp. 63-71, Business Source Complete, EBSCOhost, viewed 22 April 2014.

Erdogan, B. (1999) Celebrity Endorsement: A Literature Review, Journal Of Marketing Management, 15(4), pp. 291-314, Business Source Complete, EBSCOhost, viewed 19 April 2014.

Erdogan, B.Z., Baker, M.J. (1999) Celebrity Endorsement: Advertising Agency Managers' Perspective, CyberJournal of Sport Marketing, 3(3), Business Source Complete, EBSCOhost, viewed 18 April 2014.

Forkan, J. (1980) Product Matchup Key to Effective Star Presentations, Advertising Age, 51(1), p. 42, Business Source Complete, EBSCOhost, viewed 19 April 2014.

Friedman, H.H., Termini, S., Washington, R. (1976) The Effectivness of Advertisements Utilising Four Types of Endorsers, Journal of Advertising, 6, Summer, pp. 22-24, Business Source Complete, EBSCOhost, viewed 21 April 2014.

Goldman, L., Bennett, D. (2011) 12 Athlete Endorsements That Were Lost To Scandal, Business Insider, Electronic Version, available at http://www.businessinsider.com/12-athlete-endorsements-that-were-lost-toscandal-2011-8?op=1, viewed 19 April 2014

Ha, L., McCann, K. (2008) An Integrated Model of Advertising Clutter in Offline and Online Media, International Journal of Advertising, 27(4), p. 16, Business Source Complete, EBSCOhost, viewed 18 April 2014.

Hammer, P., Riebe, E., Kennedy, R. (2009) How Clutter Affects Advertising Effectivness, Journal of Advertising Research, 49(2), pp. 159-163, Business Source Complete, EBSCOhost, viewed 19 April 2014.

Hovland, C., Weiss, W. (1951) The influence of source credibility on communication effectiveness, Public Opinion Quarterly, 15(1), pp. 635-650, Business Source Complete, EBSCOhost, viewed 21 April 2014.

Hovland, C., Janis, L., Kelley, H. (1953) Communication and Persuasion, New Haven: Yale University Press

Jeong, Y., Kim, Y., Zhao, X. (2011) Competing from Consumer Memory in Television Advertising: An Empirical Examination of the Impacts of Non-Editorial Clutter on Brand Memory in Mega-Event Broadcasts, International Journal of Advertising, 30(4), p. 61-70, Business Source Complete, EBSCOhost, viewed 19 April 2014.

Kamins, M.A. (1990) An Investigation into the "Match-up" Hypothesis in Celebrity Advertising, When Beauty May Be Only Skin Deep, Journal of Advertising, 19(1), pp. 4-13, Business Source Complete, EBSCOhost, viewed 22 April 2014.

Kirby, J. (2013) Creative That Cracks the Code. (cover story), Harvard Business Review, 91(3), pp. 86-89, Business Source Complete, EBSCOhost, viewed 21 April 2014. 
Louie, T., Kulik, R., \& Jacobson, R. (2001) When Bad Things Happen to the Endorsers of Good Products, Marketing Letters, 12(1), pp. 13-23, Business Source Complete, EBSCOhost, viewed 19 April 2014.

Macur, J. (2013) Nike Chooses to Sever Its Ties With Livestrong, New York Times, Electronic Edition, available at http://www.nytimes.com/2013/05/29/sports/cycling/nike-to-cut-ties-with-livestrong.html?_r=0, accessed 19 April 2013

Mathur, L.K., Mathur, I., Rangan, N. (1998) The Wealth Effects Associated with a Celebrity Endorser: The Michael Jordan Phenomenon, Journal of Advertising Research, 37(3), pp. 67-73, Business Source Complete, EBSCOhost, viewed 16 April 2014.

McCracken, G. (1989) Who is the celebrity endorser? Cultural Foundations of the Endorsement Process. Journal of Consumer Research, 16(1), pp. 310-321, Business Source Complete, EBSCOhost, viewed 16 April 2014.

McDonough, J. (1995) Bringing Brands to Life. Advertising Age, Special Collectors Edition, Spring, pp. 34-45, Business Source Complete, EBSCOhost, viewed 19 April 2014.

McGuire, W. (1985) Attitudes and Attitude Change, Handbook of Social Psychology, Vol. 2, eds. Gardner Lindzey and Elliot Aronson, New York: Random House

Misra, S., Beaty, S.E. (1990) Celebrity Spokeperson and Brand Congruence: An Assessment of Recall and Affect, Journal of Business Research, 21(2), pp 195-213, Business Source Complete, EBSCOhost, viewed 20 April 2014.

Money, R., Shimp, T., \& Sakano, T. (2006) Celebrity Endorsements in Japan and the United States: Is Negative Information All That Harmful?, Journal Of Advertising Research, 46(1), pp. 113-123, Business Source Complete, EBSCOhost, viewed 19 April 2014.

Mowen, J., \& Brown, S. (1981) On explaining and predicting the effectiveness of celebrity endorsers, Advances In Consumer Research, 8(1), pp. 437-441, Business Source Complete, EBSCOhost, viewed 18 April 2014.

Mukherjee, D. (2009) Impact of celebrity endorsement on brand image, Social Science Research Network Electronic Paper Collection, available from http://papers.ssrn.com/sol3/papers.cfm? abstract_id=1444814, viewed 1 May 2014

Nelson-Field, K., Riebe, E., \& Sharp, B. (2013) More Mutter About Clutter: Extending Empirical Generalizations to Facebook, Journal Of Advertising Research, 53(2), pp. 186-191, Business Source Complete, EBSCOhost, viewed 25 April 2014.

Ohanian, R. (1990) Construction and Validation of a Scale to Measure Celebrity Endorsers' Perceived Expertise, Trustworthiness, and Attractiveness, Journal Of Advertising, 19(3), pp. 39-52, Business Source Complete, EBSCOhost, viewed 26 April 2014.

Reinartz, W., \& Saffert, P. (2013) Creativity in Advertising: When It Works and When It Doesn't, Harvard Business Review, 91(6), pp. 106-112, Business Source Complete, EBSCOhost, viewed 25 April 2014.

Richards, J., \& Curran, C. (2002) Oracles on "Advertising": Searching for a Definition, Journal Of Advertising, 31(2), pp. 63-77, Business Source Complete, EBSCOhost, viewed 18 April 2014.

Rossiter, J., Percy, L. (1987) Advertising and Promotion Management, London: McGraw-Hill 
Schimmelphennig, C., Hollensen, S. (2013) Celebrity endorsements: Exploring the processes for finding the right celebrity to endorse a brand, Journal Of Brand Strategy, 2(4), pp. 366-378, Business Source Complete, EBSCOhost, viewed 18 April 2014.

Schultz, D.E. (1995) What is direct marketing?, Journal of Direct Marketing, 9(2), pp. 5-9, Business Source Complete, EBSCOhost, viewed 15 April 2014.

Shimp, T.A. (2003) Advertising, Promotion and Supplemental Aspects of Integrated marketing Communications, Sixth Edition, Nashville: Thomson South Western

Shimp, T. A. (2010) Integrated Marketing Communication in Advertising and Promotion, Eight Edition, International Edition, Nashville: Cengage Learning

Silvera, D.H., Austad, B. (2004) Factors Predicting the Effectiveness of Celebrity Endorsement Advertisements, European Journal of Marketing 38(11/12), Business Source Complete, EBSCOhost, viewed 20 April 2014.

Skourti, M. (2010), Celebrity endorsement: the impact of scandals on consumer purchase intentions, Dissertation Thesis, University of Sheffield, Sheffield

Smith, R.C. (1973) Source Credibility Context Effects, Speech Monographs, 40(1), pp. 303-309, Business Source Complete, EBSCOhost, viewed 19 April 2014.

Solomon, M.R. (2009), Consumer Behavior: Buying, Having, and Being, Upper Saddle River, New Jersey: Pearson Education

Steinberg, B. (2012) Rewind: What Celine Dion's 2003 Chrysler Ad Should Teach Us. Celebrities Don't Always Move Cars Off the Lot, Advertising Age, electronic resource, available at http:// adage.com/article/news/rewind-celine-dion-s-2003-chrysler-ad-teach/236413, viewed 18 April 2014

Thwaites, D., Lowe, B., Monkhouse, L., \& Barnes, B. (2012) The Impact of Negative Publicity on Celebrity Ad Endorsements, Psychology \& Marketing, 29(9), pp. 663-673, Business Source Complete, EBSCOhost, viewed 20 April 2014.

Till, B., \& Shimp, T. (1998) Endorsers in Advertising: The Case of Negative Celebrity Information, Journal Of Advertising, 27(1), pp. 67-82, Business Source Complete, EBSCOhost, viewed 19 April 2014.

van Nifterick, S. (2009) The link between celebrities and product promotion. A Jonnie Boer Case Study, Electronic Resource, available at http://dare.uva.nl/document/153333, viewed 21 April 2014

Voss, K.E. (2009) Using Humor in Conjunction with Negative Consequences in Advertising, Journal Of Current Issues \& Research In Advertising (CTC Press), 31(2), pp. 25-39, Business Source Complete, EBSCOhost, viewed 17 April 2014.

Wells, W., Burnett, J., Moriarty, S. (1998) Advertising Principles and Practices, 4th Edition, Upper Saddle River, New Jersey: Prentice Hall 
